\title{
Early Triassic fluctuations of the global carbon cycle: New evidence from paired carbon isotopes in the western USA basin
}

\author{
Gwénaël Caravaca ${ }^{\mathrm{a}, *}$, Christophe Thomazo ${ }^{\mathrm{a}}$, Emmanuelle Vennin ${ }^{\mathrm{a}}$, Nicolas Olivier ${ }^{\mathrm{b}}$, \\ Daniel A. Stephen ${ }^{\mathrm{f}}$, Arnaud Brayard ${ }^{\mathrm{a}}$ \\ a Biogéosciences UMR6282, CNRS, Univ. Bourgogne Franche-Comté, 6 Boulevard Gabriel, 21000 Dijon, France \\ b Laboratoire Magmas et Volcans, Univ. Clermont Auvergne, CNRS, 6 Avenue Blaise Pascal, 63178 Aubière Cedex, France \\ ${ }^{\mathrm{c}}$ Univ. Claude Bernard Lyon 1, CNRS, ENTPE, UMR 5023 LEHNA, 69622 Villeurbanne Cedex, France \\ d 1134 Johnson Ridge Lane, West Jordan, UT 84084, USA \\ e 140 South 700 East, Spanish Fork, UT 84660, USA \\ ${ }^{\mathrm{f}}$ Department of Earth Science, Utah Valley University, Orem, UT 84058, USA
} Théophile Cocquerez $^{\mathrm{a}}$, Gilles Escarguel ${ }^{\mathrm{c}}$, Emmanuel Fara ${ }^{\mathrm{a}}$, James F. Jenks ${ }^{\mathrm{d}}$, Kevin G. Bylund ${ }^{\mathrm{e}}$,

\section{A R T I C L E I N F O}

\section{Keywords:}

Early Triassic

Paired carbon isotopes

Net isotopic effect

Western USA basin

Smithian

Spathian

\begin{abstract}
A B S T R A C T
In the aftermath of the catastrophic end-Permian mass extinction, the Early Triassic records recurrent perturbations in the carbon isotope signal, most notably during the Smithian and through the Smithian/ Spathian Boundary (SSB; 1.5 myr after the Permian/Triassic boundary), which show some of the largest excursions of the Phanerozoic. The late Smithian also corresponds to major biotic turnovers and environmental changes, such as temperature fluctuations, that deeply impacted the recovery after the end-Permian mass extinction. Here we document the paired carbon isotope signal along with an analysis of the trace and major elements at the long-known Hot Springs section (southeastern Idaho, USA). This section records Early Triassic sediments from the Griesbachian-Dienerian up to the lower Spathian. We show that the organic and carbonate $\delta^{13} \mathrm{C}$ variations mirror the signals identified at a global scale. Particularly, the middle Smithian-SSB event represented by a negative-positive isotopic couplet is well identified and is not of diagenetic origin. We also document a positive excursion potentially corresponding to the Dienerian/Smithian Boundary. Observed Smithian-Spathian excursions are recorded similarly in both the organic and carbonate reservoirs, but the organic matter signal systematically shows unexpectedly dampened variations compared to its carbonate counterpart. Additionally, we show that variations in the net isotopic effect (i.e., $\Delta^{13} \mathrm{C}$ ) probably resulted from a complex set of forcing parameters including either a mixing between terrestrial and marine organic matter depending on the evolution of the depositional setting, or variations in the biological fractionation. We establish that the $\Delta^{13} \mathrm{C}$ signal cannot be directly related to $\mathrm{CO}_{2}$-driven temperature variations at Hot Springs. Even though the carbon isotope signal mirrors the Early Triassic variations known at the global scale, the Hot Springs signal probably also reflects local influences on the carbon isotopes that are neither diagenetic nor representative of the global exogenic carbon cycle.
\end{abstract}

\section{Introduction}

The Early Triassic ( $\sim 252$ to $\sim 247 \mathrm{Ma}$; Galfetti et al., 2007a; Baresel et al., 2017) is generally portrayed as a time interval of high ecological stress in the aftermath of the end-Permian mass extinction. This interval is also characterized by large-scale fluctuations of the carbon cycle and harsh marine conditions, including a combination of ocean acidification, euxinia, extreme seawater temperature and fluctuating productivity (e.g., Payne and Clapham, 2012; Song et al., 2012; Sun et al., 2012;
Romano et al., 2013; Pietsch and Bottjer, 2014). Various geochemical analyses indicate that fluctuations in sea surface temperatures (SST) continued throughout the Early Triassic, sometimes being associated with large and rapid $\delta^{13} \mathrm{C}$ shifts (Payne et al., 2004; Galfetti et al., 2007a; Grasby et al., 2013; Sun et al., 2012; Romano et al., 2013) and marked extinction events (e.g., Orchard, 2007; Brayard et al., 2009; Hochuli et al., 2016). Several works have documented a marked $\delta^{13} \mathrm{C}$ negative excursion during the middle Smithian, immediately followed by a positive excursion across the Smithian/Spathian Boundary (SSB) in

\footnotetext{
* Corresponding author.

E-mail address: gwenael.caravaca@u-bourgogne.fr (G. Caravaca).
} 


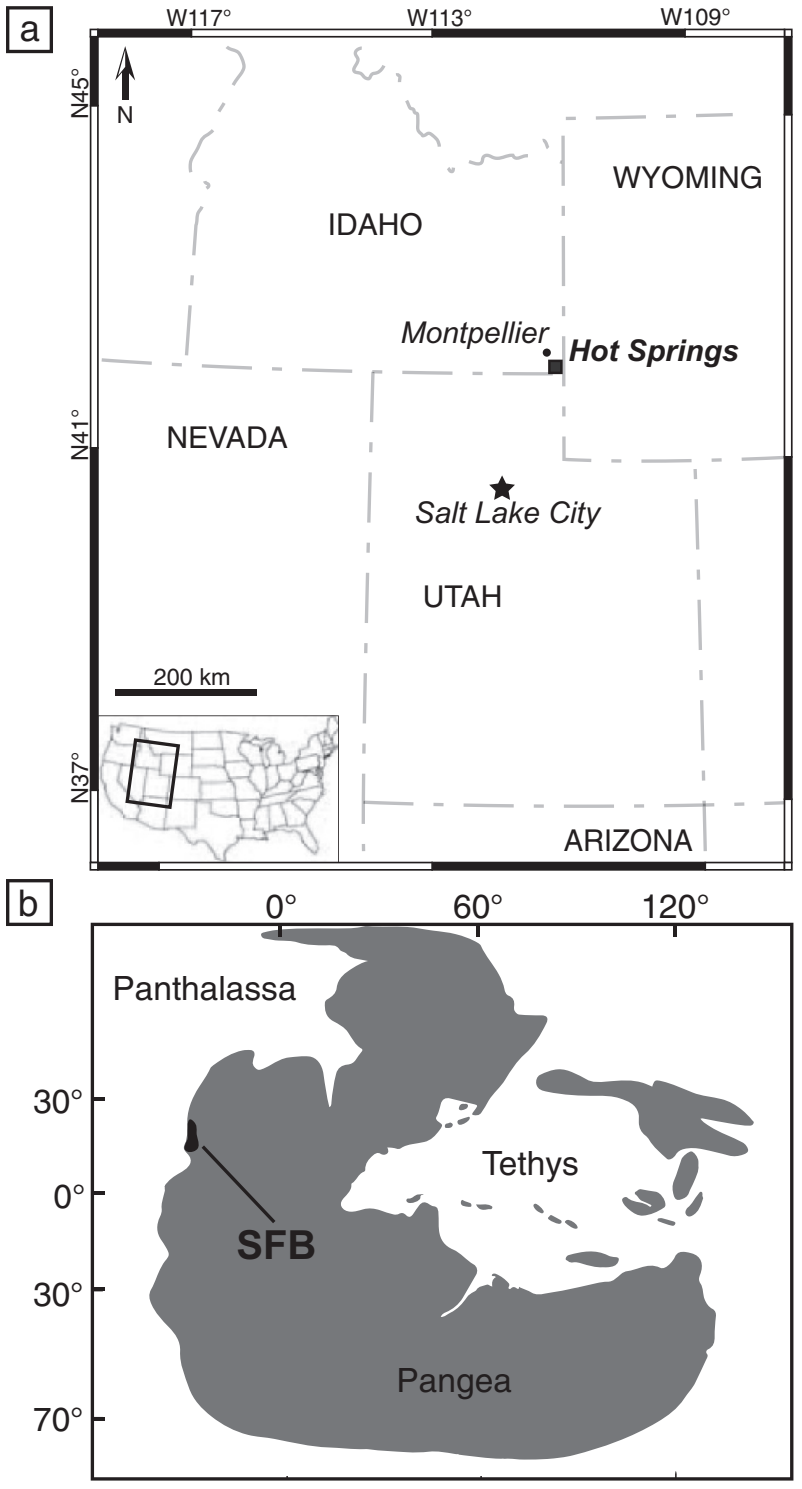

Fig. 1. (a) Map of the studied area and location of the Hot Springs section. (b) Early Triassic location of the Sonoma Foreland Basin.

different paleoenvironments within the Tethys and northern Panthalassa (Payne et al., 2004; Galfetti et al., 2007a, 2007b; Horacek et al., 2007a, 2007b, 2009; Hermann et al., 2011; see also Fig. 1 in Thomazo et al., 2016). This global signal is measured either on carbonate or organic matter (e.g., Grasby et al., 2013). However, it is rarely documented in both reservoirs simultaneously (see discussion in Thomazo et al., 2016). The observed signal is thus commonly interpreted to result from variations in the $\delta^{13} \mathrm{C}$ of the seawater dissolved inorganic carbon (DIC) reservoir (e.g., Zeebe, 2012). Proposed triggering mechanisms for the middle Smithian negative excursion involve (i) a massive release of ${ }^{12} \mathrm{C}$-enriched $\mathrm{CO}_{2}$ from volcanogenic (Sobolev et al., 2011) or thermogenic (Payne and Kump, 2007) sources, or (ii) a decrease in the organic carbon flux buried in the sedimentary record (Payne et al., 2004; Meyer et al., 2011). Concomitant periods of sustained authigenic carbonate production, decoupled from the seawater DIC reservoir, have also been documented based on carbon and sulfur isotope signals (Thomazo et al., 2016). Globally, the carbon isotope signal around the Dienerian/Smithian Boundary is less known than for the middle Smithian and the SSB due to worldwide uncertainties of biostratigraphy, synchronicity and magnitude of observed $\delta^{13} \mathrm{C}$ excursions (e.g., Horacek et al., 2007b).

Greenhouse climate conditions prevailed during the middle-upper
Smithian, in combination with anoxia on some shelf environments and potential acidification of surface waters due to elevated $\mathrm{pCO}_{2}$ attributed to large-scale greenhouse gas injections from the Siberian traps (Galfetti et al., 2007a; Romano et al., 2013). These harsh conditions may have turned lethal for marine faunas (Song et al., 2009; Sun et al., 2012; Pietsch and Bottjer, 2014; Pietsch et al., 2016). Relative cooling events are observed during the lower Smithian and lower Spathian. They are interpreted to result from the drawdown of $\mathrm{CO}_{2}$ by an enhanced biological pump (Payne and Kump, 2007). The global scenario arising from these studies is therefore a direct link between potential temperature variations and fluctuations in the exogenic carbon cycle: the "cool" lower Smithian and lower Spathian could be associated with a sustained biological pump and high $\delta^{13} \mathrm{C}$ records, disrupted by a warming event during the middle-upper Smithian triggered by ${ }^{12} \mathrm{C}$-enriched $\mathrm{CO}_{2}$ atmospheric releases due to intense volcanism. These fluctuations may have generated a biotic crisis during the upper Smithian.

Direct access to the geological record of $\mathrm{CO}_{2}$ concentrations is a challenging question (e.g., Retallack, 2001). However, coupled carbon isotope data from organic matter and carbonate measured in pristine rocks (i.e., not affected by diagenetic remobilization) can provide insights about changing concentrations of dissolved $\mathrm{CO}_{2}$ in the ocean $\left(\left[\mathrm{CO}_{2}\right]_{\mathrm{aq}}\right.$ ) (Hayes et al., 1999; Sansjofre et al., 2011). Indeed, the carbon isotope difference measured between carbonates and organic matter, $\Delta \Delta^{13} \mathrm{C}_{\text {carb-org }}$, strongly depends on the $\left[\mathrm{CO}_{2}\right]_{\mathrm{aq}}$ (Hayes et al., 1999). Only a few studies reported paired carbon measurements performed on the same samples through the critical Smithian-Spathian transition (Brühwiler et al., 2009; Hermann et al., 2011; Meyer et al., 2013; Sun et al., 2015; Thomazo et al., 2016). Additionally, available $\Delta \Delta^{13} \mathrm{C}_{\text {carb-org }}$ datasets from these studies cannot be used to reconstruct $\left[\mathrm{CO}_{2}\right]_{\mathrm{aq}}$ on the Smithian-Spathian interval because the resolution of the sampling is not sufficient (Brühwiler et al., 2009; Hermann et al., 2011; Meyer et al., 2013; Sun et al., 2015) or because of the secondary (e.g., diagenetic) modification of the isotopic record (Thomazo et al., 2016). Here we perform high-resolution measurements of the paired carbon isotope signal together with elementary (trace and major elements) compositions of 177 pristine samples encompassing the middle to upper (?) Permian to lower Spathian interval at the Hot Springs section (southeastern Idaho, USA). We show that the carbon isotope signals of both carbonate and organic matter are primary and are coupled through multiple $\delta^{13} \mathrm{C}$ excursions. Our results reveal that the magnitudes of the isotopic shifts are dampened in the organic matter reservoir compared to its inorganic carbonate counterpart. The resulting variations in the $\Delta^{13} \mathrm{C}_{\text {carb-org }}$ signal are discussed in terms of mixing with the detrital flux of organic matter and changes in biological fractionation.

\section{Geological settings}

Sampling has been carried out on the Permian to lower Spathian sedimentary succession of the Hot Springs (HS) section (GPS coordinates: $\mathrm{N} 42.114299^{\circ}, \mathrm{W}-111.249599^{\circ}$; $\sim 24 \mathrm{~km}$ south of Montpelier, Idaho, Fig. 1a). These sediments reflect deposition within the highlysubsiding northern part of the shallow Sonoma Foreland Basin (SFB) (Kummel, 1954, 1957; Caravaca et al., in press). This basin was located on the western Pangea margin at a near-equatorial position during the Early Triassic (Fig. 1b). The base of the section encompasses middle to upper(?) Permian sediments characterized by phosphatic spiculites of the Phosphoria Fm. (Wardlaw and Collison, 1986; Carrol et al., 1998), and the major regional Permian-Triassic unconformity (PTU; Brayard et al., 2013). Recent findings by Davydov et al. (2016) suggested the potential existence of a continuous Permian-Triassic (PT) record in neighboring localities of southernmost Idaho. However, at HS, only evidence for a discontinuity has been observed between Permian and Triassic sediments. For instance, conglomerates reworking phosphatic clasts from the underlying Phosphoria Fm. occur at the base of the Triassic part of the section (see below and Paull and Paull, 1986; Wignall and Hallam, 1992). No accurate age is known for deposits 


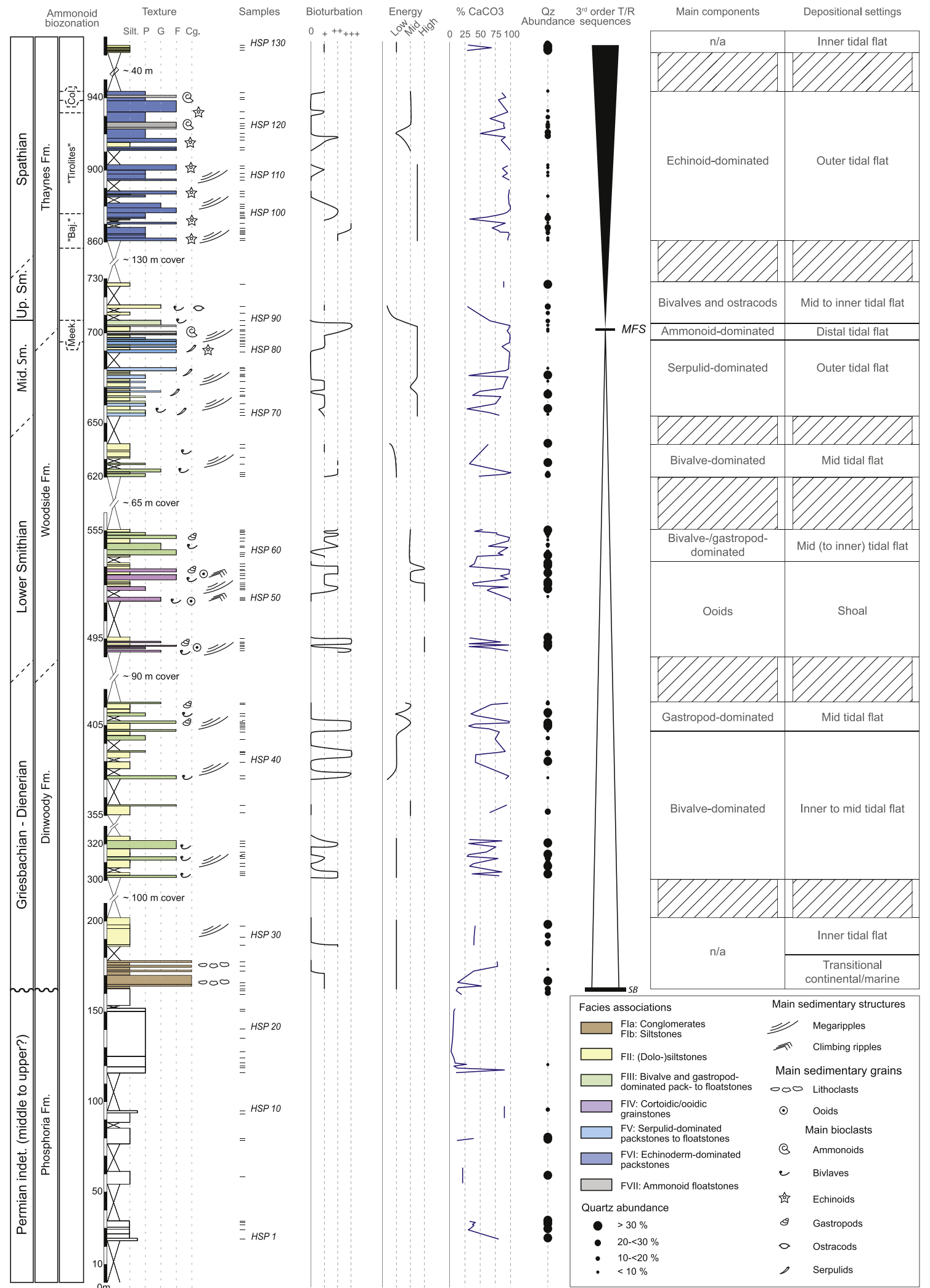

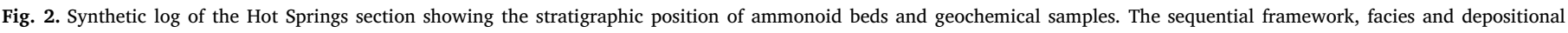

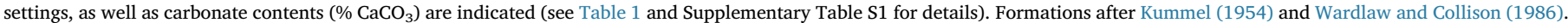

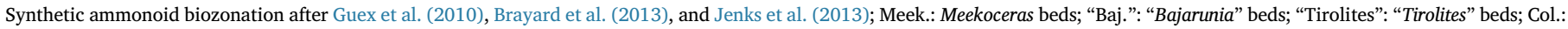

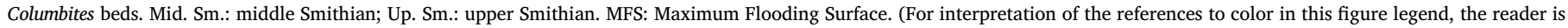
referred to the web version of this article.) 
immediately below the PTU, but following Davydov et al. (2016), part of them might be Upper Permian in age. Permian part of the hiatus included within the PTU is therefore hard to precisely constrain, but might be of long duration regarding the Late Permian.

The siltstones and carbonates of the Early Triassic Dinwoody, Woodside and Thaynes formations at the HS section were deposited in proximal marine environments (Kummel, 1954) and illustrate the global rise in sea level recorded for the Early Triassic (Haq et al., 1987; Embry, 1997). No marked unconformity can be observed between each successive formation along the section and at the scale of southeastern Idaho (e.g., Kummel, 1957; Paull and Paull, 1993) and no major erosion nor reworked material can be observed within these levels. The upper part of the HS section is biostratigraphically well calibrated using the regional synthetic frame including the successive middle Smithian to lower Spathian ammonoid Meekoceras, "Bajarunia", "Tirolites" and Columbites beds, which are commonly found in the SFB (Kummel, 1954, 1957; Guex et al., 2010; Brayard et al., 2013; Jenks et al., 2013; Jattiot et al. in press; Fig. 2). Lower strata of the Dinwoody Fm. are Griesbachian to Dienerian based on the occurrence of Claraia and lingulid beds (e.g., Kummel, 1954, 1957). This is supported by the presence of conodonts Hindeodus typicalis and Isarcella isarca in the basal beds indicating a mid-Griesbachian age (Paull et al., 1985). Usually, the lower boundary of the Thaynes Fm. is regionally identified at the base of the Smithian ledge-forming Meekoceras beds for convenience. However, these limestone deposits are included within a high-order sequence in continuity with underlying rocks (e.g., Embry, 1997) and only represent part of the early-middle Smithian (Jattiot et al. in press). It thus implies that the Dienerian/Smithian boundary (DSB) as well as the lower to middle Smithian transition at HS are mainly recognized using regional lithostratigraphy (after e.g. Kummel, 1954, 1957) and also by chemostratigraphy using comparisons with known global carbon isotopic signals (e.g., Payne et al., 2004; Galfetti et al., 2007a; Richoz et al., 2007; Horacek et al., 2009; Hermann et al., 2011; Grasby et al., 2013). Comparisons with other known carbon isotopic signals worldwide indicate that the Dienerian to middle Smithian transition is probably an expanded succession at HS. This is in agreement with the high sedimentation rates reported for this place and time interval ( $\sim 650 \mathrm{~m} / \mathrm{Myr}$, Caravaca et al., in press). As the DSB is not yet formally defined based on biostratigraphical markers (see proposals of Tong et al., 2004; Krystyn et al., 2007 and Richoz et al., 2007), we determined its approximate position by using a positive $\delta^{13} \mathrm{C}$ excursion, as observed at some other localities (e.g., Horacek et al., 2007a, 2007b, 2007c; Hermann et al., 2011; Clarkson et al., 2013; Metcalfe et al., 2013). Overall, the HS section shows an almost continuous Early Triassic succession up to the middle Spathian, although minor hiatuses under the temporal resolution of this work might exist without significant consequence on our interpretations of the geochemical trends.

\section{Sedimentary features and depositional environment}

The Early Triassic part of the HS section consists of a succession of fine marine siltstones (Griesbachian to early Smithian; historically assigned to the Dinwoody and Woodside Fms. of Kummel, 1954, 1957) and bioclastic carbonates (Smithian-Spathian Thaynes Fm.), with an increasing amount of carbonate components toward the top of the section (Fig. 2). The depositional environments reflect a large and shallow inner ramp evolving from an embayment system to an open tidal flat. Seven facies (FI to FVII, Table 1) help to discriminate three main environmental domains: (1) transitional continental to marine, (2) tidal flat and (3) open marine.

\subsection{Transitional continental to marine environment}

At the very base of the section, channelized dm-thick conglomerates (FI; Fig. 2, Table 1) are composed of pluri-centimetric clasts. Channels
(FIa) are embedded in siltstones (FIb) and barren of faunas. Clasts observed in conglomerate facies FIa are derived from the underlying Permian Phosphoria Fm. and indicate a local reworking of this material. The low biotic content (rare bivalves), the channelized conglomerates and the silt-dominated facies argue for a transitional continental to marine domain in a flood plain embayment.

\subsection{Tidal flat}

The tidal flat environment is characterized by five facies consisting of mixed siliciclastic and carbonate components that together indicate a transition from inner to outer tidal flat settings. The vertical and lateral successions of facies suggest a "facies mosaic" pattern (as illustrated in Wright and Burgess, 2005; Vennin et al., 2015; Olivier et al., 2016). The (dolo)siltstones (FII; Fig. 2, Table 1) show rare organisms, mud-draping, rare $\mathrm{dm}$ - to pluri-metric megaripples and locally-abundant bioturbations and indicate the most proximal, low to moderate energy and tidedominated conditions. Its terrigenous content (up to $>30 \%$, Fig. 2) mainly consists of sub-rounded (locally sub-angular) quartz grains, with a mean size around $70 \mu \mathrm{m}$. Mica and glauconite grains can also be found locally. The bivalve and gastropod-rich facies (FIII; Fig. 2, Table 1) is associated with dm- to m-thick beds of dolosiltstones (facies FII, Fig. 2). It shows dm- to pluri-metric megaripples. The presence of mud-drapes, mudclasts and bidirectional laminations argues for a tidedominated environment (Johnson and Baldwin, 1996). These facies correspond to inner to mid tidal flat settings. They vertically change into cortoidic and ooidic packstones to grainstones (FIV; Fig. 2, Table 1) deposited in subtidal high-energy shoals, as indicated by the presence of type 1 ooids (Strasser, 1986). The serpulid-dominated packstones to floatstones (FV; Fig. 2, Table 1) display the highest carbonate content of the whole section (up to $\sim 99 \%$ ), and are associated with the presence of hummocky cross-stratifications and bioclast-dominated tempestitic beds. The echinoderm-dominated packstones (FVI; Fig. 2, Table 1) are marked by a recrudescence of terrigenous inputs during the lower Spathian (compared to the middle-upper Smithian). Both serpulid- and echinoderm-dominated facies display $\mathrm{dm}$ - to $\mathrm{m}$-megaripples and represent outer tidal flat settings.

\subsection{Open marine environment}

The more open marine conditions recorded in the section correspond to the middle Smithian ammonoid floatstones (FVII; Fig. 2, Table 1). These beds show accumulations of ammonoid shells, as well as intense bioturbation. They correspond to the maximum flooding surface recorded at HS (Fig. 2). This agrees with the regional 3rd order cyclicity observed elsewhere in the basin (e.g., Mineral Mountains area, Vennin et al., 2015) or at a larger scale (Embry, 1997). This facies represents distal tidal flat settings.

\section{Analytical methods}

A total of 177 bulk rock samples were collected. Bulk rock samples were sorted to eliminate recrystallizations and calcified veins, and then powdered to $<60 \mu \mathrm{m}$ using a ring and puck mill at the Biogéosciences Laboratory of the Université de Bourgogne Franche-Comté, Dijon, France. Organic carbon isotope compositions $\left(\delta^{13} \mathrm{C}_{\text {org }}\right)$ and Total Organic Carbon (TOC) contents were measured on carbonate-free residues. Sample powders reacted with $\mathrm{HCl}(6 \mathrm{~N})$ at room temperature for $24 \mathrm{~h}$ followed by $4 \mathrm{~h}$ at $80^{\circ} \mathrm{C}$ to remove carbonate phases (Thomazo et al., 2009). Residues were rinsed with deionized distilled water until neutral, centrifuged ( $3500 \mathrm{rpm}$ for $5 \mathrm{~min}$ ), and dried at $50{ }^{\circ} \mathrm{C}$ overnight. Aliquots of dried decarbonated samples $(\sim 3-60 \mathrm{mg})$ were then weighed in tin capsules. TOC content and $\delta^{13} \mathrm{C}_{\text {org }}$ measurements were performed at the Biogéosciences Laboratory of the Université de Bourgogne Franche-Comté, Dijon, France, on a Vario MICRO cube elemental analyzer (Elementar, Hanau, Germany) coupled in contin- 
Table 1

Description and characterization of the 7 facies identified in the Hot Springs section and their corresponding depositional settings.

\begin{tabular}{|c|c|c|c|c|c|c|c|c|}
\hline Facies & $\begin{array}{l}\text { Biotic } \\
\text { components }\end{array}$ & $\begin{array}{l}\text { Non-biotic } \\
\text { elements }\end{array}$ & Matrix & Preservation & Structures & Energy & $\begin{array}{l}\text { Depositional } \\
\text { setting }\end{array}$ & $\begin{array}{l}\text { Main } \\
\text { environmental } \\
\text { domains }\end{array}$ \\
\hline $\begin{array}{l}\text { FI: (a) } \\
\text { Conglomerates } \\
\text { and (b) } \\
\text { siltstones }\end{array}$ & $\begin{array}{l}\text { Rare bivalves, } \\
\text { vertebrate } \\
\text { fragments }\end{array}$ & $\begin{array}{l}\text { (a) Sub-rounded } \\
\text { to sub-angular } \\
\text { clasts, } \\
\text { phosphatic } \\
\text { grains, ooids, } \\
\text { peloids; (b) } \\
\text { quartz grains }\end{array}$ & $\begin{array}{l}\text { (a) and (b) } \\
\text { Peloids and silts }\end{array}$ & (a) Broken shells & $\begin{array}{l}\text { (a) Erosion base, } \\
\text { matrix supported, } \\
\text { m-to dam } \\
\text { channels; (b) silty } \\
\text { facies }\end{array}$ & $\begin{array}{l}\operatorname{High}(\mathrm{a}) \text { to } \\
\text { low (b) }\end{array}$ & $\begin{array}{l}\text { Flood plain } \\
\text { embayment; }\end{array}$ & $\begin{array}{l}\text { Transitional } \\
\text { continental to } \\
\text { marine } \\
\text { environment }\end{array}$ \\
\hline $\begin{array}{l}\text { FII: (a) (Dolo-) } \\
\text { siltstones and } \\
\text { (b) Ostracod- } \\
\text { rich laminated } \\
\text { mudstones }\end{array}$ & $\begin{array}{l}\text { Bivalves, and } \\
\text { (b) ostracods }\end{array}$ & $\begin{array}{l}\text { (a) Sub-rounded } \\
\text { silty terrigenous } \\
\text { elements } \\
\text { (mainly quartz, } \\
\text { micas), rare } \\
\text { peloids and } \\
\text { glauconite } \\
\text { grains; (b) Dolo- } \\
\text { mudstones }\end{array}$ & $\begin{array}{l}\text { Micrite and } \\
\text { microsparite, } \\
\text { dolomite }\end{array}$ & $\begin{array}{l}\text { Locally fragmented } \\
\text { shells, bioturbation }\end{array}$ & $\begin{array}{l}\text { (a) Mud drapes, } \\
\text { planar to oblique } \\
\text { laminations, } \\
\text { loading structures, } \\
\text { ripples and dm-to } \\
\text { m-megaripples; } \\
\text { (b) laminated } \\
\text { dolomudstones } \\
\text { with fenestral } \\
\text { porosity (possible } \\
\text { microbial } \\
\text { structures?) }\end{array}$ & $\begin{array}{l}\text { Low to } \\
\text { medium }\end{array}$ & $\begin{array}{l}\text { Inner tidal } \\
\text { flat }\end{array}$ & Tidal flat \\
\hline $\begin{array}{l}\text { FIII: Bivalve and } \\
\text { gastropod- } \\
\text { dominated } \\
\text { packstones to } \\
\text { floatstones }\end{array}$ & $\begin{array}{l}\text { Bivalves, } \\
\text { gastropods, } \\
\text { rare } \\
\text { echinoderms } \\
\text { and very rare } \\
\text { serpulids }\end{array}$ & $\begin{array}{l}\text { Terrigenous silty } \\
\text { grains (quartz, } \\
\text { mica), } \\
\text { mudclasts, } \\
\text { phosphatic } \\
\text { grains }\end{array}$ & Microdolomite & $\begin{array}{l}\text { Bioturbation (high } \\
\text { intensity), locally } \\
\text { oriented and } \\
\text { disarticulated bivalves, } \\
\text { fragmented and } \\
\text { complete gastropods, } \\
\text { "umbrella" structures } \\
\text { under valves }\end{array}$ & $\begin{array}{l}\text { Dm-to m (locally } \\
\text { pluri-m) } \\
\text { megaripples, mud } \\
\text { drapes }\end{array}$ & $\begin{array}{l}\text { Medium to } \\
\text { high }\end{array}$ & Mid tidal flat & \\
\hline $\begin{array}{l}\text { FIV: } \\
\text { Cortoidic/ooidic } \\
\text { packstonesto } \\
\text { grainstones }\end{array}$ & $\begin{array}{l}\text { Bivalves, } \\
\text { gastropods, } \\
\text { echinoderms, } \\
\text { rare vertebrate } \\
\text { fragments }\end{array}$ & $\begin{array}{l}\text { Cortoids, ooids } \\
\text { (type 1, Strasser, } \\
\text { 1986), peloids, } \\
\text { phosphatic and } \\
\text { quartz grains }\end{array}$ & $\begin{array}{l}\text { Peloids or } \\
\text { micrite, } \\
\text { microsparite }\end{array}$ & $\begin{array}{l}\text { Fragmented and } \\
\text { disarticulated shells }\end{array}$ & $\begin{array}{l}\text { Ripples, climbing } \\
\text { ripples, m-to } \\
\text { pluri-m } \\
\text { megaripples }\end{array}$ & $\begin{array}{l}\text { High to } \\
\text { very high }\end{array}$ & Shoal & \\
\hline $\begin{array}{l}\text { FV: Serpulid- } \\
\text { dominated } \\
\text { packstones to } \\
\text { floatstones }\end{array}$ & $\begin{array}{l}\text { Serpulids, } \\
\text { echinoderms, } \\
\text { bivalves, } \\
\text { gastropods, } \\
\text { rare } \\
\text { foraminifera }\end{array}$ & $\begin{array}{l}\text { Rare terrigenous } \\
\text { silty grains }\end{array}$ & $\begin{array}{l}\text { Micrite, } \\
\text { microdolomicrite }\end{array}$ & $\begin{array}{l}\text { Fragmented } \\
\text { echinoderms, coalescent } \\
\text { reworked serpulids, } \\
\text { bioturbation }\end{array}$ & $\begin{array}{l}\text { Bioclast- } \\
\text { dominated } \\
\text { tempestites } \\
\text { (showing grading), } \\
\text { HCS (dm-high) }\end{array}$ & $\begin{array}{l}\text { Medium to } \\
\text { high }\end{array}$ & $\begin{array}{l}\text { Outer tidal } \\
\text { flat }\end{array}$ & \\
\hline $\begin{array}{l}\text { FVI: } \\
\text { Echinoderm- } \\
\text { dominated } \\
\text { packstones }\end{array}$ & $\begin{array}{l}\text { Echinoderms, } \\
\text { bivalves, } \\
\text { gastropods and } \\
\text { rare } \\
\text { brachiopods(?) }\end{array}$ & Quartz grains & $\begin{array}{l}\text { Micrite and } \\
\text { microdolomite }\end{array}$ & $\begin{array}{l}\text { Bioturbation (local high } \\
\text { intensity), }\end{array}$ & $\begin{array}{l}\text { Ripples and dm-to } \\
\text { m-megaripples }\end{array}$ & High & & \\
\hline $\begin{array}{l}\text { FVII: Ammonoid } \\
\text { floatstones }\end{array}$ & $\begin{array}{l}\text { Ammonoids, } \\
\text { serpulids, } \\
\text { echinoderms, } \\
\text { bivalves and } \\
\text { gastropods }\end{array}$ & Rare peloids & Micrite & $\begin{array}{l}\text { complete and oriented } \\
\text { ammonoids }\end{array}$ & Bioaccumulations & Medium & $\begin{array}{l}\text { Distal tidal } \\
\text { flat }\end{array}$ & $\begin{array}{l}\text { Open marine } \\
\text { environment }\end{array}$ \\
\hline
\end{tabular}

uous flow mode to an IsoPrime stable isotope ratio mass spectrometer (Isoprime, Manchester, UK). USGS40 certified reference material $\left(\mathrm{C}=40.8 \mathrm{wt} \% ; \delta^{13} \mathrm{C}_{\mathrm{VPDB}}=-26.2 \%\right.$ ) was used for calibration. The carbon isotopic composition is expressed in delta notation and reported in permil (\%) relative to the Vienna Pee Dee Belemnite (VPDB) standard; external reproducibility based on duplicate analyses of samples is better than $\pm 0.2 \%$ o $(1 \sigma)$. Results are reported in Supplementary Table S1.

Carbonate carbon and oxygen isotope analyses $\left(\delta^{13} \mathrm{C}_{\text {carb }}\right.$ and $\delta^{18} \mathrm{O}_{\text {carb }}$ ) were carried out on powdered bulk-rock samples at the Biogéosciences Laboratory of the Université de Bourgogne FrancheComté, Dijon, France. The samples (300 to $6000 \mu \mathrm{g}$ ) were loaded into septum screwed glass tubes for isotopic analyses. The tubes were flushed via the autosampler with He and evacuated to remove atmospheric gases. Each sample was reacted with $500 \mu \mathrm{l}$ of $100 \%$ phosphoric acid at $90{ }^{\circ} \mathrm{C}$ for $17 \mathrm{~min}$ using an online carbonate preparation line coupled to an Isoprime Elementar mass spectrometer (Isoprime, Manchester, UK). Inorganic carbonate content $\left(\% \mathrm{CaCO}_{3}\right)$ was quantified manometrically from the $\mathrm{CO}_{2}$ yield; all isotopic values are reported in the standard $\delta$-notation in permil (\%) relative to VPDB by assigning a $\delta^{13} \mathrm{C}$ value of $+1.95 \%$ and a $\delta^{18} \mathrm{O}$ value of $-2.20 \%$ to the NBS19 international standard. The long-term reproducibility of the NBS19 replicate analyses (three months) is better than $\pm 0.1 \%$ ( $1 \sigma)$ and \pm $0.12 \%$ o $(1 \sigma)$ for carbon and oxygen isotopes, respectively. Results are reported in Supplementary Table S1.

Major and trace element analyses were performed on 108 selected samples using an ICP-MS at the Activation Laboratory (Actlabs) in Ancaster, Canada. The method used is Lithium Metaborate/Tetraborate Fusion ICP and ICP-MS. Reproducibility was checked by seven duplicate and replicate analyses of laboratory standards, and is better than 

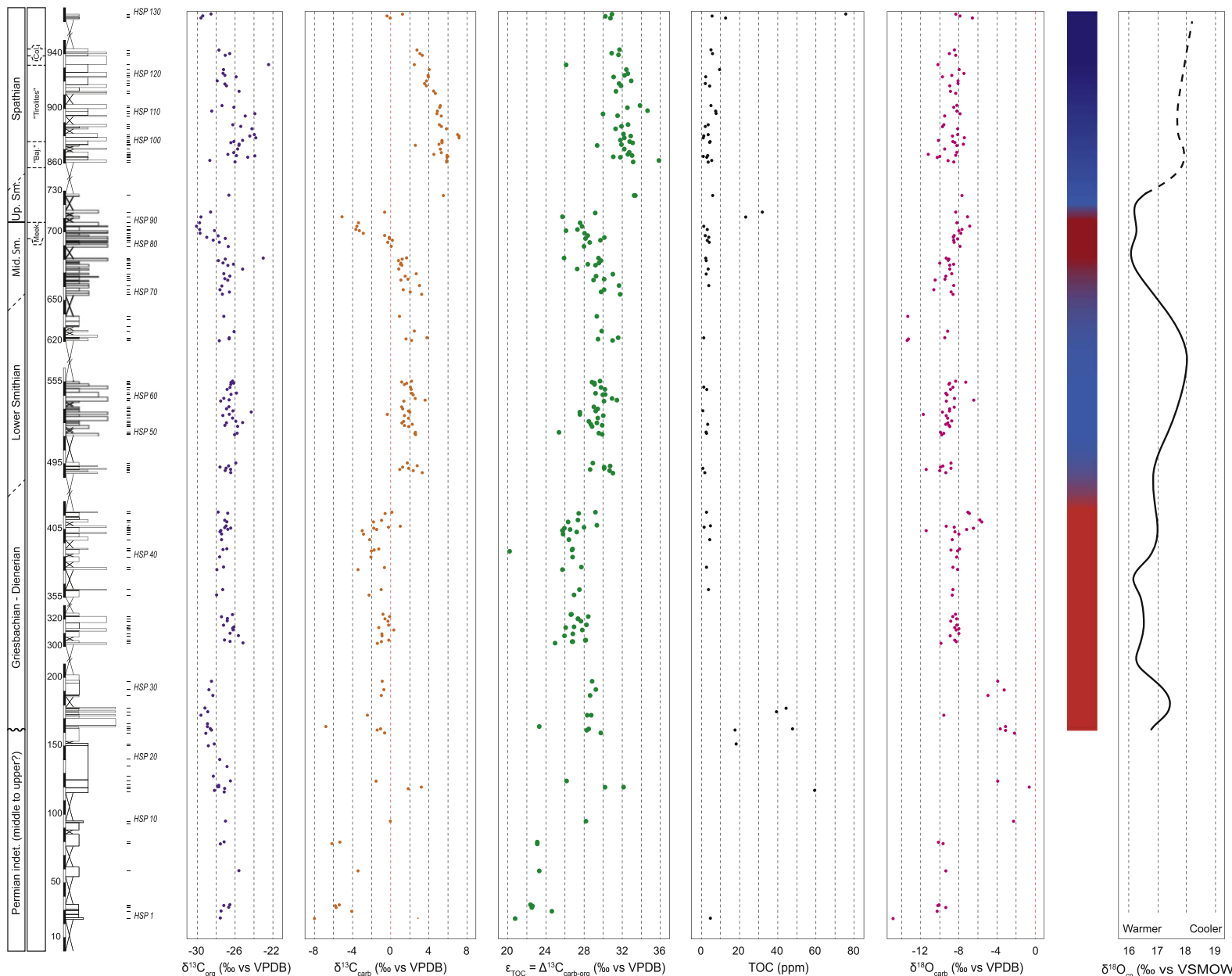

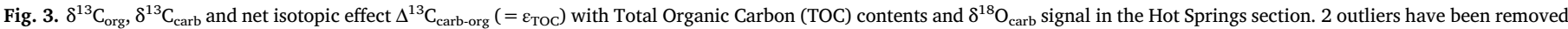

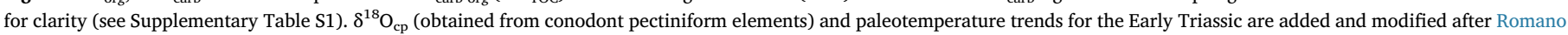
et al. (2013). (For interpretation of the references to color in this figure legend, the reader is referred to the web version of this article.)

$2 \%(1 \sigma)$ for major and trace elements. Results are reported in Supplementary Table S2.

\section{Results}

\subsection{Carbonate concentration and isotope signal}

Overall, carbonate concentration shows an important variability with a mean value of 66.4 ( $\pm 29.4 \mathrm{wt} \%, 1 \sigma$, Fig. 2, Supplementary Table S1). Highest concentrations are reached in serpulid- and ammonoid-dominated facies (FV and FVII, Fig. 2) near and within the Meekoceras beds (middle Smithian), with lasting high carbonate concentrations up to $99.0 \mathrm{wt} \%$. The $\delta^{13} \mathrm{C}_{\text {carb }}$ values vary from -8.0 to $+7.2 \%$, with a mean value of 1.0 ( $\pm 3.1 \%$, $1 \sigma$, Fig. 3, Supplementary Table S1). The $\delta^{13} \mathrm{C}_{\text {carb }}$ signal records three significant variations along the section: a ${ }^{13} \mathrm{C}$-enrichment across the potential Dienerian/Smithian Boundary (DSB); a negative isotopic excursion during the middle Smithian, followed by a positive peak across the SSB; and a decreasing trend $\left({ }^{12} \mathrm{C}\right.$-enrichment) toward the top of the section. The $\delta^{18} \mathrm{O}_{\text {carb }}$ signal ranges from -14.9 to $-0.6 \%$, with a mean value of $-8.5 \%$ o ( $\pm 1.9 \%$, $1 \sigma$, Fig. 3 \& Supplementary Table S1). No significant trend is observed throughout the Triassic part of the section, but strong covariation of the $\delta^{13} \mathrm{C}_{\text {carb }}$ and of the $\delta^{18} \mathrm{O}_{\text {carb }}$ signals is evidenced during the Permian interval (Fig. 3). The positive trend in $\delta^{13} \mathrm{C}_{\text {carb }}$ observed here through the DSB is in agreement with several signals reported worldwide (e.g., Horacek et al., 2007a, 2007b, 2007c; Richoz et al., 2007; Hermann et al., 2011; Clarkson et al., 2013; Metcalfe et al.,
2013). The identified DSB shift is of smaller magnitude than that of the SSB (Fig. 3).

\subsection{Organic matter concentration and isotope signals}

Overall, the TOC concentration ranges from 1.0 to $75.6 \mathrm{ppm}$, with a mean value of $9.2 \mathrm{ppm}$ ( $\pm 15.0 \mathrm{ppm}, 1 \mathrm{\sigma}$, Fig. 3, Supplementary Table $\mathrm{S} 1)$. The TOC concentration shows low values and almost no variation along the section, except for an important peak in the upper Smithian $(32.0 \mathrm{ppm})$, and small-scale variations during the Permian (from $\sim 30$ to $60 \mathrm{ppm}$ ). Throughout the section, the $\delta^{13} \mathrm{C}_{\text {org }}$ ranges from -30.1 to $-22.4 \%$, with a mean value of $-27.0( \pm 1.3 \%$, 1 o, Fig. 3 , Supplementary Table S1). The $\delta^{13} \mathrm{C}_{\text {org }}$ signal records similar variations to that of the $\delta^{13} \mathrm{C}_{\text {carb }}$ signal except for the DSB where no variation is observed. A negative isotopic excursion during the middle Smithian, followed by a positive peak across the SSB is observed, as well as a decreasing trend $\left({ }^{12} \mathrm{C}\right.$-enrichment) toward the top of the section.

\subsection{Paired carbon isotopes signal}

The $\Delta^{13} \mathrm{C}_{\text {carb-org }}$ signal shows a strong variability between 18.95 and $34.6 \%$, with a mean value of 27.8 ( $\pm 2.7 \%$, $1 \sigma$, Fig. 3 , Supplementary Table S1). Its evolution follows that of the above-mentioned $\delta^{13} \mathrm{C}_{\text {carb }}$ and $\delta^{13} \mathrm{C}_{\text {org }}$ signals, with three significant excursions along the section. First, a large increase in $\Delta^{13} \mathrm{C}_{\text {carb-org values is observed across the DSB. }}$ Second, a coeval and equally important decrease is demonstrated during the middle Smithian, immediately followed by a positive peak 

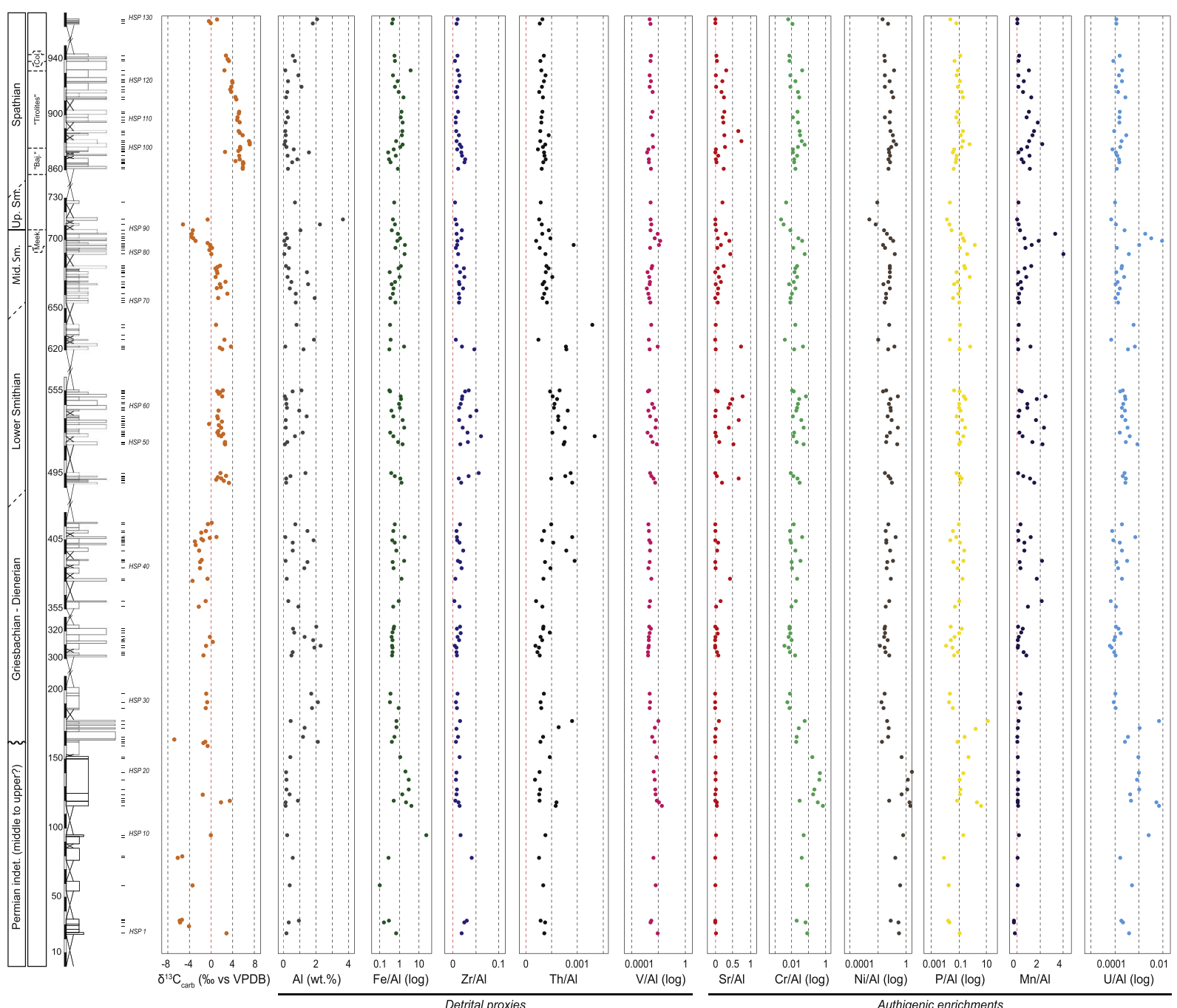

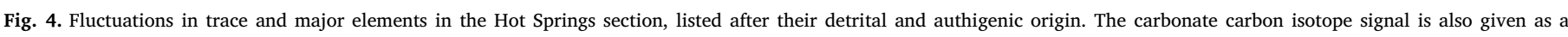

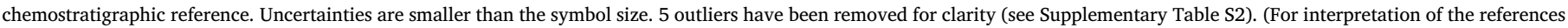
to color in this figure legend, the reader is referred to the web version of this article.)

across the SSB; and a decreasing trend can be seen toward the top of the section.

\subsection{Concentrations in major and trace elements}

\subsubsection{Detrital proxies}

While $\mathrm{Al}$ concentrations are given in wt $\%$, other major and trace element proportions are expressed as Al-normalized ratios to avoid a potential dilution effect (Tribovillard et al., 2006). Correlations between major and trace elements and $\mathrm{Al}$ concentrations are given in the form of the Spearman correlation coefficient ( $r$ ) and their associated $p$ value $(p)$.

Al concentrations range from 0.1 to $3.7 \%$, with a mean value of 0.7 ( $\pm 0.7 \%, 1 \sigma$, Fig. 4, Supplementary Table S2) and show no significant variation along the section with the exception of a peak within the upper Smithian. Because $\mathrm{Al}$ is typically of detrital origin and usually immobile during diagenesis (Böning et al., 2004), a cross-plot of a given element versus $\mathrm{Al}$ concentrations indicates whether the element concentration is dominantly controlled by the detrital flux or not. Here, $\mathrm{Fe}$ / $\mathrm{Al}, \mathrm{V} / \mathrm{Al}, \mathrm{Th} / \mathrm{Al}$ and $\mathrm{Zr} / \mathrm{Al}$ ratios show a strong correlation with $\mathrm{Al}$ concentrations $\left(r=0.80^{* * *}\right.$ for $\mathrm{Fe} / \mathrm{Al}, \quad r=0.81^{* * *}$ for $\mathrm{V} / \mathrm{Al}$, $r=0.91^{* * *}$ for $\mathrm{Th} / \mathrm{Al}$ and $r=0.86^{* * *}$ for $\mathrm{Zr} / \mathrm{Al}$ ). This suggests that these elements are associated with the $\mathrm{Al}$ flux, and have thus mainly a detrital origin. The $\mathrm{Fe} / \mathrm{Al}$ ratio ranges from 0.1 to 21.4, with a mean value of 1.0 ( $\pm 2.1,1 \sigma$, Fig. 4, Supplementary Table S2). The V/Al ratio ranges from $1.33 \times 10^{-3}$ to $18.07 \times 10^{-3}$, with a mean value of $3.67 \times 10^{-3}\left( \pm 2.86 \times 10^{-3}, 1 \sigma\right.$, Fig. 4, Supplementary Table S2). The Th/Al ratio ranges from $0.18 \times 10^{-3}$ to $1.33 \times 10^{-3}$, with a mean value of $0.44 \times 10^{-3}\left( \pm 0.22 \times 10^{-3}, 1 \sigma\right.$, Fig. 4, Supplementary Table S2). The $\mathrm{Zr} / \mathrm{Al}$ ratio ranges from $3.71 \times 10^{-3}$ to $61.59 \times 10^{-3}$, with a mean value of $15.94 \times 10^{-3}$ ( $\pm 10.91 \times 10^{-3}, 1 \sigma$, Fig. 4, Supplementary Table S2). These signals show no significant variation along the section, except for the $\mathrm{V} / \mathrm{Al}$ ratio that displays a weak peak in the Meekoceras beds (middle Smithian).

\subsubsection{Authigenic enrichments}

The Mn/Al, P/Al, Sr/Al, Cr/Al, Ni/Al and U/Al ratios (Fig. 4, Supplementary Table S2) are not significantly correlated to Al concentrations $\left(r=-0.03, p=0.77\right.$ for $\mathrm{Mn} / \mathrm{Al}, r=0.51^{* * *}$ for $\mathrm{P} / \mathrm{Al}$, $r=-0.44^{* * *}$ for Sr/Al, $r=0.55^{* * *}$ for $\mathrm{Cr} / \mathrm{Al}, r=0.50^{* * *}$ for Ni/ $\mathrm{Al}, r=0.57 * * *$ for $\mathrm{U} / \mathrm{Al}$ ). This indicates authigenic enrichments related to variations in the paleoenvironmental conditions. The $\mathrm{Mn} /$ $\mathrm{Al}$ ratio ranges from 0 (HSP 4) to 4.0 (HSP 80), with a mean value of 0.6 ( $\pm 0.8,1 \sigma$, Fig. 4, Supplementary Table S2). This signal barely varies along the section, except in the Meekoceras beds (middle Smithian) where small-scale variations are recorded. The $\mathrm{P} / \mathrm{Al}$ ratio ranges from 0.01 to 13.47 , with a mean value of 0.34 ( $\pm 1.38,1 \sigma$, Fig. 4, 
Supplementary Table S23). P/Al ratio shows a significant decrease within the upper Smithian interval. Another increase of the $\mathrm{P} / \mathrm{Al}$ ratio is documented within the "Bajarunia" beds (lower Spathian). The Sr/Al ratio ranges from $3.78 \times 10^{-3}$ to $771.42 \times 10^{-3}$, with a mean value of $133.61 \times 10^{-3}\left( \pm 188.60 \times 10^{-3}, 1 \sigma\right.$, Fig. 4, Supplementary Table S2), with no important variation along the section. The $\mathrm{Cr} / \mathrm{Al}$ ratio ranges from $2.18 \times 10^{-3}$ to $665.42 \times 10^{-3}$, with a mean value of $41.66 \times 10^{-3}\left( \pm 93.54 \times 10^{-3}, 1 \sigma\right.$, Fig. 4, Supplementary Table S2). This signal shows no significant variation until the upper Smithian where a marked decrease is observed. The latter is immediately followed by an increase across the SSB. Ni/Al ratio ranges from $2.45 \times 10^{-3}$ to $2492.77 \times 10^{-3}$, with a mean value of $155.49 \times 10^{-3}\left( \pm 360.46 \times 10^{-3}, 1\right.$ o, Fig. 4, Supplementary Table S2), showing a similar evolution to the $\mathrm{Cr} / \mathrm{Al}$ ratio signal with no significant variation until the upper Smithian, where a marked decrease is observed. $\mathrm{Ni} / \mathrm{Al}$ ratio values increase again across the SSB. The U/Al ratio ranges from $0.06 \times 10^{-3}$ to $9.15 \times 10^{-3}$, with a mean value of $0.58 \times 10^{-3}\left( \pm 1.39 \times 10^{-3}, 1 \sigma\right.$, Fig. 4, Supplementary Table S2). $\mathrm{U} / \mathrm{Al}$ ratio values do not show any noticeable variation except across the middle-upper Smithian transition where a significant peak is observed.

\section{Interpretations}

\subsection{Evolution of the depositional environment}

The HS depositional environment corresponds to a shallow inner ramp evolving from an embayment system to an open tidal flat during the Early Triassic. The observed mosaic facies pattern exhibits important vertical and lateral changes reflecting fluctuations in bathymetry and hydrodynamism. The HS section also exhibits mixed terrigenous and carbonate contents composed of (dolo-)siltstones and mud to bioclastic limestone layers. The fine grained terrigenous components may have originated from eastern and/or southern sources such as the Uncompahgre high of remnant Ancestral Rocky Mountains (Kluth and Coney, 1981; Blakey, 2008). The presence of sedimentary structures such as ripples or megaripples highlights episodes of important hydrodynamism. Bioturbation occurs throughout the entire section with varying intensity, even within bioclastic free layers (Fig. 2), suggesting oxygenated bottom-waters during deposition.

The Griesbachian-Dienerian to lower Smithian interval corresponds to a transgressive trend demonstrated by depositional conditions deeper than the ones observed at the very base of the section near the PTU (Fig. 2). The tidal flat records stronger hydrodynamic conditions as shown by the presence of ooid-rich shoals in the lowest Smithian (FIV in Table 1 and Fig. 2). The middle Smithian is characterized by the maximum carbonate content within the serpulid-rich and ammonoidrich beds (FV and FVII in Table 1 and Fig.2). While included in the transgressive trend, Facies FV (Table 1) marks the outermost tidal flat settings, whereas a maximum of accommodation occurs at the level of the Meekoceras beds immediately before the upper Smithian. The upper Smithian corresponds to the maximum extent of the inundated area within the basin and it is characterized by an important flooding of the ramp and of the continental borders (e.g., Blakey, 2008; Brayard et al., 2013; Olivier et al., 2014, 2016; Vennin et al., 2015). Consequently, reworking of continental soils in the most proximal zones of the whole basin may have occurred in the upper Smithian, as argued by evidence of influx of terrestrial organic remains found in the northern part of the basin at some restricted places (personal observations). The lower Spathian marks a return to outer tidal flat conditions characterized by echinoderm-dominated carbonated beds (FVI) associated with and evolving toward an increase in fine terrigenous siliciclastic material (FII; Table 1, Fig. 2). This indicates the onset of a regressive trend after the maximum flooding that occurred during the upper Smithian (Fig. 2).

\subsection{Major and trace elements}

\subsubsection{Detrital influx}

$\mathrm{Th}$ and $\mathrm{Zr}$ are thought to have a siliciclastic origin and are thus interpreted to be linked to potential terrigenous inputs when they are correlated to Al concentrations (Rachold and Brumsack, 2001; Sauvage et al., 2013). In the HS section, these elements show a strong correlation to $\mathrm{Al}$ (see Section 5.4.1.). They can therefore be considered as good proxies for detrital influxes. Additionally, the V/Al ratio is strongly correlated to $\mathrm{Al}$ (see Section 5.4.1.), likely indicating a terrigenous origin of $\mathrm{V}$, even if this trace element is usually used as a paleoredox marker (e.g., Tribovillard et al., 2006, 2008). The Zr/Al, Th/Al and V/ $\mathrm{Al}$ ratios show restricted ranges of variation throughout the entire section (Fig. 4). This is in agreement with the observed continuous and homogenous clastic inputs (quartz- and mica-rich) and granulometry (FII; Table 1, Fig. 2). A relative stability in source and/or grain size of the clastic inputs can be inferred (Calvert et al., 1996), suggesting continuous continental weathering conditions.

\subsubsection{Paleoproductivity}

$\mathrm{P} / \mathrm{Al}$ and $\mathrm{Ni} / \mathrm{Al}$ ratios are used as proxies for variations in primary productivity if they are not correlated to $\mathrm{Al}$ concentration (i.e., representing an authigenic accumulation; Tribovillard et al., 2006). Phosphorous is a micronutrient, which is mainly incorporated by the phytoplankton. Enrichments of $\mathrm{P}$ within sediments are therefore usually interpreted as evidence of a high organic matter (OM) supply, in a productive environment such as present-day coastal upwelling zones (Calvert and Pedersen, 1993; Algeo and Maynard, 2004; Tribovillard et al., 2006; Sauvage et al., 2013). Withdrawal of Ni from the water column and scavenging within the $\mathrm{OM}$ is responsible for the sedimentary accumulation of Ni (Nameroff et al., 2004; Naimo et al., 2005; Tribovillard et al., 2006; Sauvage et al., 2013). Variations of these elements can therefore be used to infer variations in OM supply and burial, and thus may be interpreted in terms of primary productivity pulses.

At $\mathrm{HS}$, both $\mathrm{P} / \mathrm{Al}$ and $\mathrm{Ni} / \mathrm{Al}$ ratios show weak variations, except in the upper Smithian-lower Spathian interval, where a noticeable decrease in $\mathrm{P} / \mathrm{Al}$ and $\mathrm{Ni} / \mathrm{Al}$ ratios is observed across the middle/upper Smithian transition. These variations cannot result from lithological differences as facies observed in this part of the section are similar, being mainly represented by serpulid- and ammonoid-dominated packstones to floatstones (FV and FVII, Fig. 2). Thus, these P/Al and $\mathrm{Ni} / \mathrm{Al}$ fluctuations can be linked to a change in productivity.

However, these variations may also result from early diagenesis and remineralization of the $\mathrm{OM}$ under reducing conditions, especially if they are concomitant with a change in anoxic condition markers (e.g., U; Sauvage et al., 2013). The presence of a concomitant peak in the U/ Al signal (Fig. 4) may argue in favor of the remobilization of the $P$ rather than for a primary signal. Ni can be incorporated into sulfides under locally euxinic conditions within the sediment (Tribovillard et al., 2006). P is known to be easily released under anoxic conditions, remobilized and then enriched within the pore-water in the absence of high primary productivity (Benitez-Nelson, 2000; Tribovillard et al., 2006). The reliability of $P$ as a proxy for paleoproductivity is therefore questionable here. The absence of coeval increase between the TOC content and $\mathrm{Ni} / \mathrm{Al}$ and $\mathrm{P} / \mathrm{Al}$ ratios better argues for remineralization processes rather than variation in paleoproductivity (Sauvage et al., 2013).

\subsubsection{Paleoredox conditions}

Sedimentary analyses support well-oxygenated conditions for the water column and the bottom waters throughout the entire section. The analyses of Redox Sensitive Trace Elements (RSTE) such as Mn, U, V and Mo can help to document short-lived episodes of reducing conditions at the bottom-water/sediment interface and in the upper early diagenetic sediment (Algeo and Maynard, 2004; Algeo and Lyons, 
2006; Tribovillard et al., 2006; Riquier et al., 2006; Sauvage et al., 2013). Here, Mo was under the detection limit and the V/Al ratio is used as a detritism proxy due to its high correlation to Al. Conversely, $\mathrm{Mn} / \mathrm{Al}$ and $\mathrm{U} / \mathrm{Al}$ ratios are barely correlated to $\mathrm{Al}$ (see Section 5.4.2).

Both the $\mathrm{Mn} / \mathrm{Al}$ and $\mathrm{U} / \mathrm{Al}$ ratios show narrow ranges of variations, except for the serpulid-rich and ammonoid-rich beds (including the middle Smithian Meekoceras beds, Figs. 2, 4). There, the U/Al ratio shows a pronounced peak, concomitant with the short-lived peak in P/ Al ratio. This $U$ enrichment can reflect dysoxic/anoxic conditions (Calvert and Pedersen, 1993; Algeo and Maynard, 2004; Tribovillard et al., 2006; Sauvage et al., 2013). The unique significant enrichment in the $\mathrm{V} / \mathrm{Al}$ ratio is documented from the same interval, probably resulting from the $\mathrm{V}$ sensitivity to authigenic concentration in reducing environments. A slight concomitant enrichment in the $\mathrm{Mn} / \mathrm{Al}$ ratio also occurs within the Meekoceras beds. During episodes of dysoxic/anoxic conditions, depletion in Mn concentration (associated with enrichment in U) is however expected (Mangini et al., 2001; Kuhn et al., 2005; Westermann et al., 2010; Sauvage et al., 2013). Here, a strong correlation $(r=0.91 * * *)$ between the $\mathrm{Mn}$ concentration and the $\mathrm{CaCO}_{3}$ content is observed, suggesting that the $\mathrm{Mn}$ concentration reflects lithological variation rather than paleoredox conditions (Pratt et al., 1991). Finally, paleoredox markers indicate that some transient and slightly dysoxic/anoxic condition could have developed within the sediment or at the bottom-water/sediment interface within the interval including the Meekoceras beds.

\subsubsection{The peculiar case of chromium}

Cr fluctuations are difficult to interpret in terms of paleoenvironments as they can reflect both detritism and paleoredox conditions (Tribovillard et al., 2006, 2008). At HS, the $\mathrm{Cr}$ is only correlated to Al concentration and Th/Al ratio $\left(r=0.55^{* * *}\right.$ and $r=0.53^{* * * *}$, respectively). Moreover, $\mathrm{Cr}$ variations do not mirror those for detrital markers such as $\mathrm{Zr} / \mathrm{Al}$ or $\mathrm{Th} / \mathrm{Al}$ ratios. Thus, $\mathrm{Cr}$ accumulation may at least partially correspond to an authigenic enrichment. Additionally, $\mathrm{Cr}$ is strongly correlated to $\mathrm{Ni}$ (Fig. 4, $r=0.93^{* * *}$ ). In the presence of certain dissolved metals $(\mathrm{Ni}, \mathrm{Pb}, \mathrm{Cu}), \mathrm{Cr}$ can form $\mathrm{MeCrO}_{4}$ complexes (Tribovillard et al., 2008). Formation of such complexes is mediated by the presence of $\mathrm{H}_{2} \mathrm{~S}$ as a by-product of bacterial sulfate-reduction (BSR), or resulting from the mixing and reworking of the stocked sedimentary $\mathrm{H}_{2} \mathrm{~S}$ (Tribovillard et al., 2008). We hypothesize that the formation of $\mathrm{MeCrO}_{4}$ complexes, and more particularly complexes involving $\mathrm{Ni}$, were potentially triggered by pulses of reducing $\mathrm{H}_{2} \mathrm{~S}$-rich conditions within the sediment.

\subsection{Carbon isotope records}

\subsubsection{Preservation of isotope signals}

6.3.1.1. Carbonate. The carbonate isotope signal is sensitive to diagenesis and prone to change due to circulation of diagenetic fluids and/or processes of dissolution/recrystallization forming secondary carbonates (Sansjofre et al., 2011 and references therein). Most of the time, carbon content in fluids and fluid/rock ratios are low compared to the high carbon content of carbonate rocks and cannot modify significantly their carbon isotope composition. However, when diagenetic fluids are enriched in DIC of organic origin (i.e. with low $\delta^{13} \mathrm{C}$ ), both $\delta^{13} \mathrm{C}_{\text {carb }}$ and $\delta^{18} \mathrm{O}_{\text {carb }}$ are likely to be overprinted and it is usually admitted that a positive correlation between $\delta^{13} \mathrm{C}_{\text {carb }}$ and $\delta^{18} \mathrm{O}_{\text {carb }}$ or a positive trend between $\delta^{13} \mathrm{C}_{\text {carb }}$ and carbonate content indicate a diagenetic overprint (Sansjofre et al., 2011). Figure 5a and b show no correlation between $\delta^{13} \mathrm{C}_{\text {carb }}$ versus $\% \mathrm{CaCO}_{3}$ and $\delta^{13} \mathrm{C}_{\text {carb }}$ versus $\delta^{18} \mathrm{O}_{\text {carb }}$, respectively, during the Triassic interval, suggesting a $\delta^{13} \mathrm{C}_{\text {carb }}$ signal inherited from the water column and immune from late remobilization processes. However, the Permian record displays a positive correlation $\left(\mathrm{r}=0.75^{* *}\right)$ between $\delta^{13} \mathrm{C}_{\text {carb }}$ and $\delta^{18} \mathrm{O}_{\text {carb }}$, interpreted as a secondary process overprint of the signal (Fig. 5b). Due to the presence of diagenetic artifacts in the Permian signal, we therefore cannot use these data to reconstruct the evolution of HS paleoenvironments for this time interval.

The diagenetic overprint of $\delta^{13} \mathrm{C}_{\text {carb }}$ can also be tested using the Mn/ $\mathrm{Sr}$ ratio. During alteration by meteoric water, $\mathrm{Sr}$ is expelled from carbonate while $\mathrm{Mn}$ is incorporated, thus increasing the $\mathrm{Mn} / \mathrm{Sr}$ ratio (Banner and Hanson, 1990). The observed Mn/Sr ratio is extremely low $(\mathrm{Mn} / \mathrm{Sr}<<2)$. Moreover, no correlation between the $\mathrm{Mn} / \mathrm{Sr}$ ratio and $\delta^{13} \mathrm{C}_{\text {carb }}$ or $\delta^{18} \mathrm{O}_{\text {carb }}$ is observed (Fig. $5 \mathrm{c}$ and d), with the exception of a positive correlation $\left(r=0.78^{*}\right)$ between the $\mathrm{Mn} / \mathrm{Sr}$ ratio and $\delta^{18} \mathrm{O}_{\text {carb }}$ for Permian samples, highlighting secondary processes for this time interval only (Fig. 5d). However, given the small amount of available points for this interval, this result should be taken with caution. Variations of the $\delta^{13} \mathrm{C}_{\text {carb }}$ signal are also independent of facies or lithological changes (Figs. 2,3). Thus, no local or facies-dependent effects (e.g., preferential fluid circulation due to porosity) significantly imprint the $\delta^{13} \mathrm{C}_{\text {carb }}$ signal. Moreover, the evolution of the $\delta^{13} \mathrm{C}$ signal at $\mathrm{HS}$ is comparable to signals identified in other basins worldwide, with a marked negative excursion during the middle Smithian, followed by a positive excursion through the SSB (Fig. 6). Finally, no diagenetic overprint on the Early Triassic $\delta^{13} \mathrm{C}_{\text {carb }}$ is demonstrated at HS, and its similar evolution with $\delta^{13} \mathrm{C}_{\text {carb }}$ records from other sections worldwide is interpreted as indicating a primary $\delta^{13} \mathrm{C}_{\text {carb }}$ signal.

6.3.1.2. Organic matter. The reliability of $\delta^{13} \mathrm{C}_{\text {org }}$ to reflect the carbon isotope composition of photosynthetic primary productivity depends on the magnitude of the isotope offsets associated with depositional and post-depositional processes: (i) OM bacterial degradation and secondary $\mathrm{OM}$ inputs by heterotrophic and chemoautotrophic organisms during the early diagenesis s.l., (ii) thermal maturation of the OM during burial diagenesis and/or metamorphism, (iii) syn- or post-depositional oxidative alteration, and (iv) emplacement of hydrocarbon from another source rock.

Overall, Early Triassic samples from the western USA SFB show low OM concentrations (Supplementary Table S1; Thomazo et al., 2016). Their $\delta^{13} \mathrm{C}_{\text {org }}$ signal has therefore often been overlooked, their low TOC content casting doubt on the primary significance of the $\delta^{13} \mathrm{C}_{\text {org }}$. Nevertheless, recent studies have shown that $\delta^{13} \mathrm{C}_{\text {org }}$ signals can have a primary significance even at low TOC contents (Eigenbrode et al., 2008; Oehlert and Swart, 2014; Sansjofre et al., 2011; Johnston et al., 2012; Thomazo et al., 2009, 2016). At HS, the absence of correlation between the $\delta^{13} \mathrm{C}_{\text {org }}$ and the TOC content argues against a substantial alteration of the $\delta^{13} \mathrm{C}_{\text {org }}$ signal (Fig. 7). Similar to the $\delta^{13} \mathrm{C}_{\text {carb }}$ signal, no significant variation due to changes in lithology and/or in facies is observed and the negative-positive couplet of carbon isotopes excursions during the middle Smithian and the SSB is recognized in the OM reservoir (Fig. 6). These are evidence for a pristine record of the $\delta^{13} \mathrm{C}_{\text {org }}$ signal.

\subsubsection{Interpretation of the paired carbon isotope signal}

A parallel evolution of the $\delta^{13} \mathrm{C}_{\text {carb }}$ and $\delta^{13} \mathrm{C}_{\text {org }}$ signals is expected when perturbations of the biogeochemical carbon cycle are linked to the exogenic carbon cycle (Meyer et al., 2013). Paired organic and carbonate carbon isotopes recorded from the same sample are therefore crucial to distinguish the secular evolution of the carbon cycle (Payne et al., 2004; Payne and Kump, 2007; Meyer et al., 2011; Sobolev et al., 2011) from potential early or burial diagenetic processes (Hayes and Waldbauer, 2006; Derry, 2010; Schrag et al., 2013; Thomazo et al., 2016). Identified $\delta^{13} \mathrm{C}_{\text {carb }}$ anomalies show a tight coupling with the $\delta^{13} \mathrm{C}_{\text {org }}$ signal at the middle Smithian-SSB, but not at the DSB. Isotopic covariance in both carbonate and $\mathrm{OM}$ reservoirs is particularly well documented at a fine stratigraphic scale, such as the swings in $\delta^{13} \mathrm{C}$ in the middle Smithian-lower Spathian transition (Figs. 3, 6), suggesting a relatively well-mixed marine DIC reservoir during this interval.

The observed co-variation of carbon isotope signals for the Smithian-Spathian interval contrasts with models requiring a large dissolved organic carbon (DOC) pool (Rothman et al., 2003). Indeed, 
$\mathrm{a}$

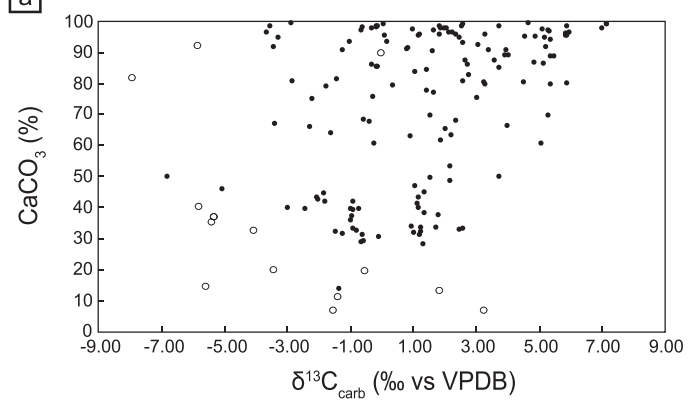

c

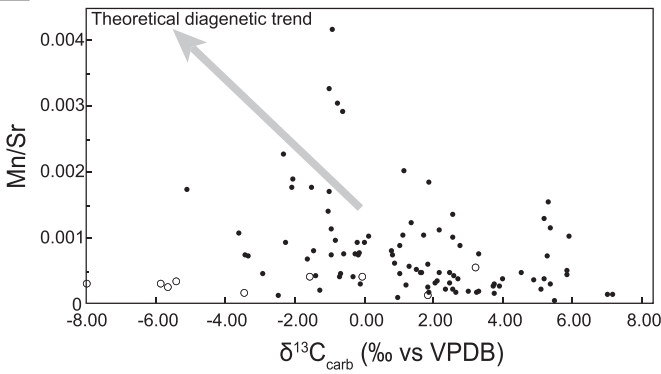

b

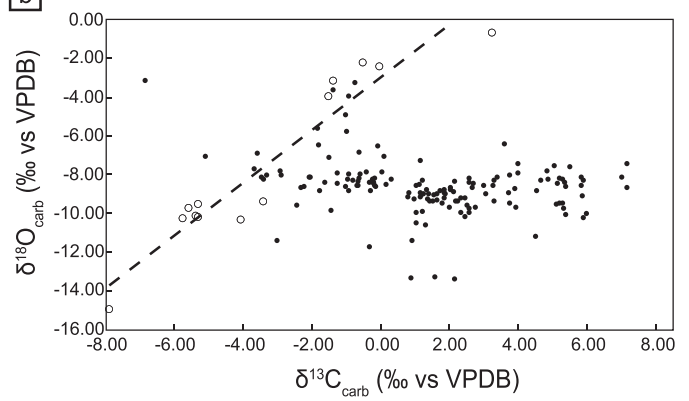

d

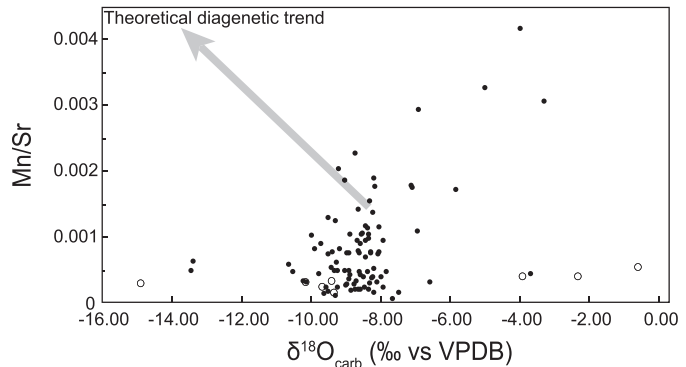

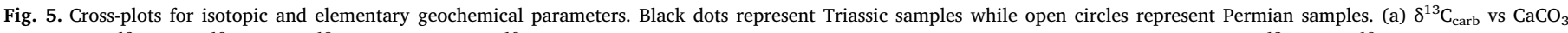

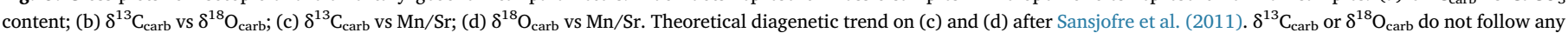

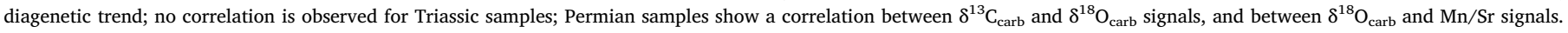

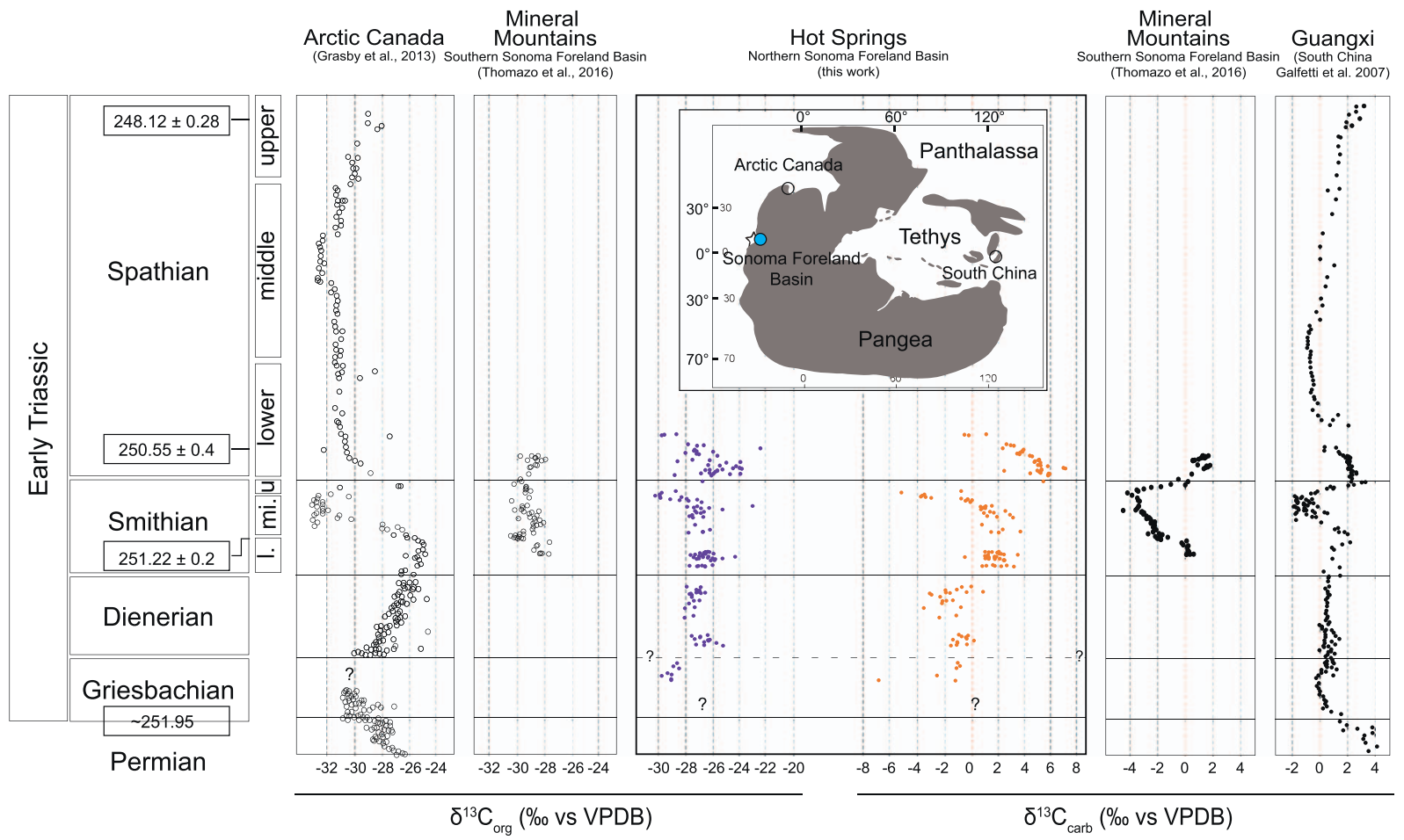

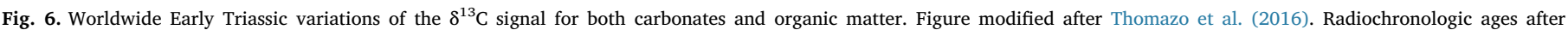

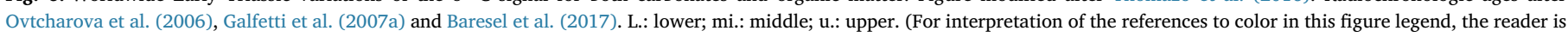
referred to the web version of this article.)

the oxidation of such a large reservoir would generate a negative $\delta^{13} \mathrm{C}_{\text {carb }}$ excursion without changing the $\delta^{13} \mathrm{C}_{\text {org }}$ (McFadden et al., 2008; Swanson-Hysell et al., 2008). Moreover, the DOC hypothesis implies pronounced changes in the redox balance of the whole basin. Theoretical kinetic considerations are also at odds with the DOC hypothesis as a trigger for the Early Triassic carbon isotope swings (Thomazo et al., 2016). Interestingly, while $\delta^{13} \mathrm{C}_{\text {carb }}-\delta^{13} \mathrm{C}_{\text {org }}$ covariation is well characterized at HS, dissimilar net isotopic offsets $\left(\Delta^{13} \mathrm{C}_{\text {carb-org }}\right)$ are associated with the DSB, the middle Smithian and the SSB. The $\delta^{13} \mathrm{C}_{\text {org }}$ signal is dampened compared to the $\delta^{13} \mathrm{C}_{\text {carb }}$ (Figs. 3, 6). Variations in the net isotopic effect $\left(\varepsilon_{\mathrm{TOC}}=\Delta^{13} \mathrm{C}_{\text {carb-org }}\right.$ ) can reflect: (i) a diagenetic smoothing of the $\delta^{13} \mathrm{C}_{\text {org }}$ signal, (ii) variations in the kinetic fractionation associated with carbon fixation (i.e. photosynthesis), or (iii) contamination with a secondary source of organic carbon. The absence of correlation between the $\delta^{13} \mathrm{C}_{\text {org }}$ and the TOC content (Fig. 7) supports a pristine record of the $\delta^{13} \mathrm{C}_{\text {org }}$ and indicates that no diagenetic 


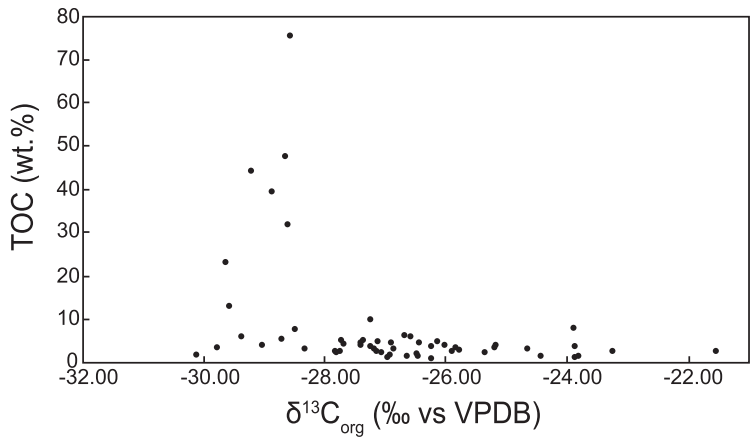

Fig. 7. $\delta^{13} \mathrm{C}_{\text {org }}$ vs TOC content cross-plot. No correlation can be observed.

alteration has modified the OM isotopic signal at HS.

The photosynthetic fractionation of carbon can vary over time according to the concentration of dissolved $\mathrm{CO}_{2}$ in the ocean $\left[\mathrm{CO}_{2}\right]_{\mathrm{aq}}$ and associated controlling mechanisms, including: the temperature, the growth rates of microorganisms (noted as $\mu \mathrm{m}$ ) and changes in cell geometries (Hayes et al., 1999). Popp et al. (1998) showed that the photosynthetic fractionation and $\mu \mathrm{m} /\left[\mathrm{CO}_{2}\right]_{\mathrm{aq}}$ are negatively correlated and that species-specific cell geometry determines the slope of the regression line. Based on this relationship, the lowering of surface water $\left[\mathrm{CO}_{2}\right]_{\mathrm{aq}}$ is expected to generate a decrease in $\varepsilon_{\mathrm{TOC}}$ at constant growth rate. Additionally, the $\delta^{13} \mathrm{C}_{\text {org }}$ signal should record a larger shift than carbonates. Conversely, an increase in cellular growth rates tends to significantly reduce $\varepsilon_{\mathrm{TOC}}$ at moderate atmospheric $\mathrm{CO}_{2}$ level $(<1500$ ppmv).

The observed $\Delta^{13} \mathrm{C}_{\text {carb-org }}$ variations may reflect Early Triassic changes in sea surface temperatures as documented by Sun et al. (2012) and Romano et al. (2013) (Fig. 3). The middle Smithian negative $\delta^{13} \mathrm{C}$ excursion is interpreted to reflect a temperature increase due to $\mathrm{CO}_{2}$ injections from the Siberian traps (Sun et al., 2012; Romano et al., 2013). Ensuing extreme greenhouse climate conditions are suggested to have triggered lethal conditions for marine faunas such as anoxia on shelf environments and acidification of surface waters (biocalcification crisis) due to elevated $\mathrm{CO}_{2}$ (hypercapnia) (e.g. Sun et al., 2012; Pietsch and Bottjer, 2014). At HS, decreases in $\varepsilon_{\mathrm{TOC}}$ are associated with warm temperatures and $\varepsilon_{\mathrm{TOC}}$ increases are concomitant with cooler episodes (Fig. 3). The $\Delta{ }^{13} \mathrm{C}_{\text {carb-org }}$ changes are thus difficult to explain in the light of temperature variations only. Extensive volcanogenic ${ }^{12} \mathrm{C}$-enriched $\mathrm{CO}_{2}$ degassing is consistent with $\delta^{13} \mathrm{C}_{\text {carb }}$ and $\delta^{13} \mathrm{C}_{\text {org }}$ Smithian negative signals. However, this should promote in turn a $\varepsilon_{\mathrm{TOC}}$ increase due to increasing surface water $\left[\mathrm{CO}_{2}\right]_{\mathrm{aq}}$.

The SSB $\delta^{13} \mathrm{C}$ positive excursion is usually said to reflect an increase in primary productivity (Payne and Kump, 2007). Our results agree with this interpretation as increasing TOC contents are associated with $\delta^{13} \mathrm{C}_{\text {carb }}$ and $\delta^{13} \mathrm{C}_{\text {org }}$ positive excursions (Fig. 3). An enhanced biological pump is therefore most likely associated with, and contributes to a drawdown of global $\mathrm{CO}_{2}$ and cooling. The surface water $\left[\mathrm{CO}_{2}\right]_{\mathrm{aq}}$ must have therefore decreased and consequently, the $\varepsilon_{\mathrm{TOC}}$ as well. This expected evolution is in contradiction with our observed trend in $\varepsilon_{\mathrm{TOC}}$ (Fig. 3). Assuming an upper Smithian stratified ocean returning to a more oxidizing state (i.e. ventilation) as suggested by Tian et al. (2014) and Sun et al. (2015), an increase of nutrient inputs into shallow environments is expected to be associated with an increase in $\mu \mathrm{m}$ (Joachimski et al., 2002). Therefore, lowered $\varepsilon_{\mathrm{TOC}}$ values should be observed, independently of any change in global $\mathrm{CO}_{2}$. Since an increase in $\varepsilon_{\mathrm{TOC}}$ is observed at $\mathrm{HS}$, neither changes in $\left[\mathrm{CO}_{2}\right]_{\mathrm{aq}}$ nor nutrient availability is suggested by paired carbon isotope variations at the DSB, middle Smithian and SSB transitions.

A lowered net isotopic effect is recorded during warm periods (Figs. 3,6 ). This can be partly explained by a significant increase in the contribution of the cyanobacterial biomass to the TOC. Indeed, the maximum fractionation factor for cyanobacteria is smaller than for eukaryotic algae (Joachimski et al., 2002). Since photosynthetic fractionation of some modern cyanobacteria is independent of the dissolved $\left[\mathrm{CO}_{2}\right]_{\mathrm{aq}}$, a bloom of cyanobacteria among the primary producers during harsh (high temperature and low $\mathrm{pH}$ ) and mesotrophic conditions may explain our results, especially the $\varepsilon_{\mathrm{TOC}}$ signal that does not reflect a $\mathrm{CO}_{2}$-dependant increase in temperature. The HS section does not show sedimentological evidence of cyanobacterial blooms through the middle-upper Smithian interval. However, several microbial deposits were described throughout the SFB for this same interval (e.g., Brayard et al., 2013; Olivier et al., 2014, 2016; Vennin et al., 2015).

In some cases, $\Delta{ }^{13} \mathrm{C}_{\text {carb-org }}$ variations can reflect a contamination by a secondary source of organic carbon, from the erosion of organic-rich sediments or the migration of hydrocarbons within the basin (Johnston et al., 2012). Thus, mixing of the water column DIC reservoir with exogenous sources of carbon can buffer the $\delta^{13} C_{\text {org }}$ signal, especially when TOC values are low. Overall, Early Triassic primary carbon isotope signals of terrestrial and marine $\mathrm{OM}$ have been reported to vary around $-22 \%$ and around $-32 \%$, respectively (Hermann et al., 2011). We observed a $\delta^{13} C_{\text {org }}$ positive excursion that is dampened compared to the $\delta^{13} \mathrm{C}_{\text {carb }}$ at the DSB (Figs. 3, 6). Such a variation in paired carbon isotopes, decoupled in magnitude, may correspond to a greater contribution of marine OM compared to terrestrial OM at this time. A decrease of the terrestrial OM contribution to the sedimentary TOC at the DSB is also in accordance with facies and paleoenvironmental changes that evolve toward more open marine conditions, as indicated by a change from bioclast-dominated to ooid-dominated facies (Fig. 2, Table 1). The globally recognized negative $\delta^{13} \mathrm{C}$ excursion during the middle Smithian is recorded in both carbon reservoirs at HS. However, the amplitude of the ${ }^{12} \mathrm{C}$-enrichment is lower in the OM. This result is difficult to explain if we hypothesize variations in the relative $\mathrm{OM}$ contributors (marine versus terrestrial). According to other known carbon isotope signals of terrestrial and marine $\mathrm{OM}$ at that time (Hermann et al., 2011), an increasing contribution of terrestrial OM would be expected to account for a lowered $\varepsilon_{\mathrm{TOC}}$ signal. The middleupper Smithian transition at HS corresponds to the maximum transgressive event (Fig. 2). In such a transgressive trend, an increase in terrestrial OM contribution to the sedimentary record is not expected. However, evidence for influx of terrestrial organic remains associated with potential reworking of continental soils is observed in the northern part of the SFB at some restricted places in the uppermost Smithian (personal observations). The subsequent positive $\delta^{13} \mathrm{C}$ shift through the SSB is recorded in both carbon reservoirs, with differing amplitudes of variation between carbonate and $\mathrm{OM}$ reservoirs and showing a more pronounced excursion in the $\delta^{13} \mathrm{C}_{\text {carb }}$ signal. The lower Spathian exhibits an increase in terrigenous material compared to the middleupper Smithian around the Meekoceras zone (Fig. 2), but again hypothesis of the mixing of terrestrial and marine OM cannot explain the observed $\Delta^{13} \mathrm{C}_{\text {carb-org }}$ signal. Both positive excursions associated with the increase in TOC is however consistent with previous interpretations that suggested a drawdown of $\mathrm{CO}_{2}$ by an enhanced biological pump (Payne and Kump, 2007).

Recently, some authors (e.g., Klaebe et al., 2017) have demonstrated that local parameters exert an important influence on the carbon isotope record, sometimes enough to overprint any global control. Here, while positive and negative excursions might be rooted to global changes, their expression may vary from one reservoir to another (i.e. carbonate and $\mathrm{OM}$ ) due to locally-controlled parameters such as ecological structure (primary producers) and sedimentary processes. Thus, the use of the $\Delta^{13} \mathrm{C}_{\text {carb-org }}$ signal as a direct tracer of the Early Triassic global $\left[\mathrm{CO}_{2}\right]_{\mathrm{aq}}$ and sea surface temperature should be taken with great caution.

\section{Conclusions}

Early Triassic sediments of the Hot Springs section were deposited 
on a large and shallow inner ramp, evolving from a transitional continental to marine embayment to a more open tidal flat. The maximum of the transgressive trend was reached during the middleupper Smithian transition.

The paired carbon isotope record and trace and major elements highlight the following features for the sedimentary succession at HS:

- No water column anoxia/euxinia is observed, in agreement with sedimentary structures and biotic associations attesting to vigorous hydrodynamic conditions. Transient and weak dysoxic/anoxic conditions may have developed within the sediment or at the bottomwater/sediment interface during the middle-upper Smithian interval.

- Known worldwide carbon isotope fluctuations for the Smithian and Spathian are recognized in both OM and carbonate $\delta^{13} \mathrm{C}$ reservoirs.

- Additionally, a positive excursion near the Dienerian/Smithian Boundary is documented on the carbonate $\delta^{13} \mathrm{C}$ signal.

- The $\delta^{13} \mathrm{C}$ signal at HS is not of secondary process/diagenetic origin, but rather primary and representative of a pristine record in both reservoirs.

- An increase in primary productivity may be responsible for the positive $\delta^{13} \mathrm{C}$ excursion observed in the upper Smithian and through the SSB, as a concomitant increase in TOC content is observed.

- At HS, variations in the net isotopic effect cannot be directly related to $\mathrm{CO}_{2}$ driven temperature variations, but they better reflect changes in OM sources: marine vs. terrestrial sources and/or the primary producers (e.g. cyanobacteria) origin.

- Finally, local influences on the carbon isotope signals, which are neither diagenetic nor representative of the global exogenic cycle, have probably largely contributed to the HS geochemical signatures. These signals could thus primarily reflect fluctuating local parameters.

\section{Acknowledgements}

This work was supported by the French Agence Nationale de la Recherche (ANR) project AFTER (ANR-13-JS06-0001-01). A.-S. Grosjean is thanked for discussions. This is a contribution to the FEDER Bourgogne Franche-Comté. We also thank two anonymous reviewers for constructive comments that helped to improve the manuscript. The Hot Springs section is located on US public land under the stewardship of the Bureau of Land Management (BLM) of the US Department of the Interior; access to this land is gratefully acknowledged.

\section{Appendix A. Supplementary data}

Supplementary data to this article can be found online at http://dx. doi.org/10.1016/j.gloplacha.2017.05.005.

\section{References}

Algeo, T.J., Lyons, T.W., 2006. Mo-total organic carbon covariation in modern anoxic marine environments: implications for analysis of paleoredox and paleohydrographic conditions. Paleoceanography 21 (1).

Algeo, T.J., Maynard, J.B., 2004. Trace-element behavior and redox facies in core shales of Upper Pennsylvanian Kansas-type cyclothems. Chem. Geol. 206 (3), 289-318.

Banner, J.L., Hanson, G.N., 1990. Calculation of simultaneous isotopic and trace element variations during water-rock interaction with applications to carbonate diagenesis. Geochim. Cosmochim. Acta 54 (11), 3123-3137.

Baresel, B., Bucher, H., Brosse, M., Cordey, F., Guodun, K., Schaltegger, U., 2017. Precise age for the Permian-Triassic boundary in South China from high-precision U-Pb geochronology and Bayesian age-depth modeling. Solid Earth Discuss. 8 (2), 361-378.

Benitez-Nelson, C.R., 2000. The biogeochemical cycling of phosphorus in marine systems. Earth Sci. Rev. 51 (1), 109-135.

Blakey, R.C., 2008. Pennsylvanian-Jurassic Sedimentary Basins of the Colorado Plateau and Southern Rocky Mountains Sedimentary Basins of the World. Elsevier Amsterdam, Netherlands, Netherlands, pp. 245-296.

Böning, P., Brumsack, H.-J., Böttcher, M.E., Schnetger, B., Kriete, C., Kallmeyer, J.,
Borchers, S.L., 2004. Geochemistry of Peruvian near-surface sediments. Geochim. Cosmochim. Acta 68 (21), 4429-4451.

Brayard, A., Escarguel, G., Bucher, H., Monnet, C., Brühwiler, T., Goudemand, N. Galfetti, T., Guex, J., 2009. Good genes and good luck: ammonoid diversity and the end-Permian mass extinction. Science 325 (5944), 1118-1121.

Brayard, A., Bylund, K.G., Jenks, J.F., Stephen, D.A., Olivier, N., Escarguel, G., Fara, E., Vennin, E., 2013. Smithian ammonoid faunas from Utah: implications for early

Triassic biostratigraphy, correlation and basinal paleogeography. Swiss J. Paleontol. 132 (2), 141-219.

Brühwiler, T., Goudemand, N., Galfetti, T., Bucher, H., Baud, A., Ware, D., Hermann, E., Hochuli, P.A., Martini, R., 2009. The Lower Triassic sedimentary and carbon isotope records from Tulong (South Tibet) and their significance for Tethyan palaeoceanography. Sediment. Geol. 222 (3), 314-332.

Calvert, S., Pedersen, T., 1993. Geochemistry of recent oxic and anoxic marine sediments: implications for the geological record. Mar. Geol. 113 (1), 67-88.

Calvert, S., Bustin, R., Ingall, E., 1996. Influence of water column anoxia and sediment supply on the burial and preservation of organic carbon in marine shales. Geochim. Cosmochim. Acta 60 (9), 1577-1593.

Caravaca, G., Brayard, A., Vennin, E., Guiraud, M., Le Pourhiet, L., Grosjean, A.-S., Thomazo, C., Olivier, N., Fara, E., Escarguel, G., Bylund, K.G., Jenks, J.F., Stephen, D.A., 2017. Controlling factors for differential subsidence in the Sonoma Foreland Basin (Early Triassic, western USA). Geol. Mag. 1-25. http://dx.doi.org/10.1017/ S0016756817000164. (in press).

Carrol, A.R., Stephens, N.P., Hendrix, M.S., Glenn, C.R., 1998. Eolian-derived siltstone in the Upper Permian Phosphoria Formation: implications for marine upwelling. Geology 26 (11), 1023-1026.

Clarkson, M., Richoz, S., Wood, R.A., Maurer, F., Krystyn, L., McGurty, D.J., Astratti, D., 2013. A new high-resolution $\delta^{13} \mathrm{C}$ record for the Early Triassic: insights from the Arabian Platform. Gondwana Res. 24 (1), 233-242.

Davydov, V.I., Crowley, J.L., Schmitz, M.D., Snyder, W.S., 2016. New U-Pb constraints identify the end-Guadalupian and possibly end-Lopingian extinction events conceivably preserved in the passive margin of North America: implication for regional tectonics. Geol. Mag. 1-13. http://dx.doi.org/10.1017/ S0016756816000959.

Derry, L.A., 2010. A burial diagenesis origin for the Ediacaran Shuram-Wonoka carbon isotope anomaly. Earth Planet. Sci. Lett. 294 (1), 152-162.

Eigenbrode, J.L., Freeman, K.H., Summons, R.E., 2008. Methylhopane biomarker hydrocarbons in Hamersley Province sediments provide evidence for Neoarchean aerobiosis. Earth Planet. Sci. Lett. 273 (3), 323-331.

Embry, A.F., 1997. Global sequence boundaries of the Triassic and their identification in the western Canada sedimentary basin. Bull. Can. Petrol. Geol. 45 (4), 415-433.

Galfetti, T., Bucher, H., Ovtcharova, M., Schaltegger, U., Brayard, A., Brühwiler, T., Goudemand, N., Weissert, H., Hochuli, P.A., Cordey, F., Guodun, K., 2007a. Timing of the Early Triassic carbon cycle perturbations inferred from new U-Pb ages and ammonoid biochronozones. Earth Planet. Sci. Lett. 258 (3-4), 593-604.

Galfetti, T., Hochuli, P.A., Brayard, A., Bucher, H., Weissert, H., Vigran, J.O., 2007b. Smithian-Spathian boundary event: evidence for global climatic change in the wake of the end-Permian biotic crisis. Geology 35 (4), 291-294.

Grasby, S., Beauchamp, B., Embry, A., Sanei, H., 2013. Recurrent Early Triassic ocean anoxia. Geology 41 (2), 175-178.

Guex, J., Hungerbühler, A., Jenks, J.F., O'Dogherty, L., Atudorei, V., Taylor, D.G., Bucher, H., Bartolini, A., 2010. Spathian (Lower Triassic) Ammonoids from Western USA (Idaho, California, Utah and Nevada). Institut de géologie et paléontologie, Université de Lausanne.

Haq, B.U., Hardenbol, J., Vail, P.R., 1987. Chronology of fluctuating sea levels since the Triassic. Science 235 (4793), 1156-1167.

Hayes, J.M., Waldbauer, J.R., 2006. The carbon cycle and associated redox processes through time. Philos. Trans. R. Soc. Lond. B 361 (1470), 931-950.

Hayes, J.M., Strauss, H., Kaufman, A.J., 1999. The abundance of ${ }^{13} \mathrm{C}$ in marine organic matter and isotopic fractionation in the global biogeochemical cycle of carbon during the past 800 Ma. Chem. Geol. 161 (1), 103-125.

Hermann, E., Hochuli, P.A., Méhay, S., Bucher, H., Brühwiler, T., Ware, D., Hautmann, M., Roohi, G., Yaseen, A., 2011. Organic matter and palaeoenvironmental signals during the early Triassic biotic recovery: the Salt Range and Surghar Range records. Sediment. Geol. 234 (1), 19-41.

Hochuli, P.A., Sanson-Barrera, A., Schneebeli-Hermann, E., Bucher, H., 2016. Severest crisis overlooked-worst disruption of terrestrial environments postdates the Permian-Triassic mass extinction. Sci. Report. 6. http://dx.doi.org/10.1038/ srep28372.

Horacek, M., Brandner, R., Abart, R., 2007a. Carbon isotope record of the P/T boundary and the Lower Triassic in the Southern Alps: evidence for rapid changes in storage of organic carbon. Palaeogeogr. Palaeoclimatol. Palaeoecol. 252 (1), 347-354.

Horacek, M., Richoz, S., Brandner, R., Krystyn, L., Spötl, C., 2007b. Evidence for recurrent changes in Lower Triassic oceanic circulation of the Tethys: the $\delta^{13} \mathrm{C}$ record from marine sections in Iran. Palaeogeogr. Palaeoclimatol. Palaeoecol. 252 (1), 355-369.

Horacek, M., Wang, X., Grossman, E.L., Richoz, S., Cao, Z., 2007c. The carbon-isotope curve from the Chaohu section, China: different trends at the Induan-Olenekian Boundary or diagenesis. Albertiana 35, 41-45.

Horacek, M., Koike, T., Richoz, S., 2009. Lower Triassic $\delta^{13} C$ isotope curve from shallowmarine carbonates in Japan, Panthalassa realm: confirmation of the Tethys $\delta^{13} \mathrm{C}$ curve. J. Asian Earth Sci. 36 (6), 481-490.

Jattiot, R., Bucher, H., Brayard, A., Brosse, M., Jenks, J., Bylund, K.G., 2017. Smithian ammonoid faunas from northeastern Nevada: implications for Early Triassic biostratigraphy and correlation within the western USA basin. Palaeontogr. Abt. A. http://dx.doi.org/10.1127/pala/2017/0070. (in press).

Jenks, J., Guex, J., Hungerbühler, A., Taylor, D.G., Bucher, H., 2013. Ammonoid 
biostratigraphy of the Early Spathian Columbites parisianus Zone (Early Triassic) at Bear Lake Hot Springs, Idaho. N. M. Mus. Nat. Hist. Sci. Bull. 61, 268-283.

Joachimski, M., Pancost, R., Freeman, K., Ostertag-Henning, C., Buggisch, W., 2002. Carbon isotope geochemistry of the Frasnian-Famennian transition. Palaeogeogr. Palaeoclimatol. Palaeoecol. 181 (1), 91-109.

Johnson, H., Baldwin, C., 1996. Shallow Clastic Seas. Sedimentary Environments: Processes, Facies and Stratigraphy. 3. pp. 232-280.

Johnston, D.T., Macdonald, F.A., Gill, B., Hoffman, P., Schrag, D.P., 2012. Uncovering the Neoproterozoic carbon cycle. Nature 483 (7389), 320-323.

Klaebe, R., Kennedy, M., Jarrett, A., Brocks, J., 2017. Local paleoenvironmental controls on the carbon-isotope record defining the Bitter Springs Anomaly. Geobiology 15 (1), 65-80.

Kluth, C.F., Coney, P.J., 1981. Plate tectonics of the ancestral Rocky Mountains. Geology 9 (1), 10-15.

Krystyn, L., Bhargava, O.N., Richoz, S., 2007. A candidate GSSP for the base of the Olenekian stage: Mud at Pin Valleay; district Lahul \& Spiti, Himachal Pradesh (western Himalaya), India. Albertiana 35, 5-29.

Kuhn, O., Weissert, H., Föllmi, K.B., Hennig, S., 2005. Altered carbon cycling and tracemetal enrichment during the late Valanginian and early Hauterivian. Eclogae Geol. Helv. 98 (3), 333-344.

Kummel, B., 1954. Triassic Stratigraphy of Southeastern Idaho and Adjacent Areas. US Government Printing Office.

Kummel, B., 1957. Paleoecology of Lower Triassic formations of southeastern Idaho and adjacent areas. Geol. Soc. Am. Mem. 67, 437-468.

Mangini, A., Jung, M., Laukenmann, S., 2001. What do we learn from peaks of uranium and of manganese in deep sea sediments? Mar. Geol. 177 (1), 63-78.

McFadden, K.A., Huang, J., Chu, X., Jiang, G., Kaufman, A.J., Zhou, C., Yuan, X., Xiao, S., 2008. Pulsed oxidation and biological evolution in the Ediacaran Doushantuo Formation. Proc. Natl. Acad. Sci. 105 (9), 3197-3202.

Metcalfe, I., Nicoll, R., Willink, R., Ladjavadi, M., Grice, K., 2013. Early Triassic (Induan-Olenekian) conodont biostratigraphy, global anoxia, carbon isotope excursions and environmental perturbations: new data from Western Australian Gondwana. Gondwana Res. 23 (3), 1136-1150.

Meyer, K., Yu, M., Jost, A., Kelley, B., Payne, J., 2011. $\delta^{13} \mathrm{C}$ evidence that high primary productivity delayed recovery from end-Permian mass extinction. Earth Planet. Sci. Lett. 302 (3), 378-384.

Meyer, K.M., Yu, M., Lehrmann, D., Van de Schootbrugge, B., Payne, J., 2013. Constraints on Early Triassic carbon cycle dynamics from paired organic and inorganic carbon isotope records. Earth Planet. Sci. Lett. 361, 429-435.

Naimo, D., Adamo, P., Imperato, M., Stanzione, D., 2005. Mineralogy and geochemistry of a marine sequence, Gulf of Salerno, Italy. Quat. Int. 140, 53-63.

Nameroff, T., Calvert, S., Murray, J., 2004. Glacial-interglacial variability in the eastern tropical North Pacific oxygen minimum zone recorded by redox-sensitive trace metals. Paleoceanography 19 (1). http://dx.doi.org/10.1029/2003PA000912.

Oehlert, A.M., Swart, P.K., 2014. Interpreting carbonate and organic carbon isotope covariance in the sedimentary record. Nat. Commun. 5. http://dx.doi.org/10.1038/ ncomms5672.

Olivier, N., Brayard, A., Fara, E., Bylund, K.G., Jenks, J.F., Vennin, E., Stephen, D.A., Escarguel, G., 2014. Smithian shoreline migrations and depositional settings in Timpoweap Canyon (Early Triassic, Utah, USA). Geol. Mag. 151 (5), 938-955.

Olivier, N., Brayard, A., Vennin, E., Escarguel, G., Fara, E., Bylund, K.G., Jenks, J.F., Caravaca, G., Stephen, D.A., 2016. Evolution of depositional settings in the Torrey area during the Smithian (Early Triassic, Utah, USA) and their significance for the biotic recovery. Geol. J. 51 (4), 600-626.

Orchard, M.J., 2007. Conodont diversity and evolution through the latest Permian and Early Triassic upheavals. Palaeogeogr. Palaeoclimatol. Palaeoecol. 252 (1), 93-117.

Ovtcharova, M., Bucher, H., Schaltegger, U., Galfetti, T., Brayard, A., Guex, J., 2006. New Early to Middle Triassic U-Pb ages from South China: calibration with ammonoid biochronozones and implications for the timing of the Triassic biotic recovery. Earth Planet. Sci. Lett. 243 (3), 463-475.

Paull, R.K., Paull, R.A., 1986. Epilogue for the Permian - a retrospective view from the Triassic in western Cordillera. Univ. Wyo. Contrib. Geol. 24, 243-252.

Paull, R.A., Paull, R.K., 1993. Interpretation of Early Triassic nonmarine-marine relations, Utah, USA. N. M. Mus. Nat. Hist. Sci. Bull. 3, 403-409.

Paull, R.K., Paull, R.A., Anderson, A.L., 1985. Conodont biostratigraphy and depositional history of the Lower Triassic Dinwoody Formation in the Meade Plate, southeastern Idaho. Utah Geol. Assoc. Publ. 14, 55-65.

Payne, J.L., Clapham, M.E., 2012. End-Permian mass extinction in the oceans: an ancient analog for the twenty-first century? Annu. Rev. Earth Planet. Sci. 40, 89-111.

Payne, J.L., Kump, L.R., 2007. Evidence for recurrent Early Triassic massive volcanism from quantitative interpretation of carbon isotope fluctuations. Earth Planet. Sci. Lett. 256 (1), 264-277.

Payne, J.L., Lehrmann, D.J., Wei, J., Orchard, M.J., Schrag, D.P., Knoll, A.H., 2004. Large perturbations of the carbon cycle during recovery from the end-Permian extinction. Science 305 (5683), 506-509.

Pietsch, C., Bottjer, D.J., 2014. The importance of oxygen for the disparate recovery patterns of the benthic macrofauna in the Early Triassic. Earth Sci. Rev. 137, 65-84.

Pietsch, C., Petsios, E., Bottjer, D.J., 2016. Sudden and extreme hyperthermals, lowoxygen, and sediment influx drove community phase shifts following the endPermian mass extinction. Palaeogeogr. Palaeoclimatol. Palaeoecol. 451, 183-196.

Popp, B.N., Laws, E.A., Bidigare, R.R., Dore, J.E., Hanson, K.L., Wakeham, S.G., 1998. Effect of phytoplankton cell geometry on carbon isotopic fractionation. Geochim. Cosmochim. Acta 62 (1), 69-77.

Pratt, L.M., Force, E.R., Pomerol, B., 1991. Coupled manganese and carbon-isotopic events in marine carbonates at the Cenomanian-Turonian boundary. J. Sediment. Res. 61 (3).

Rachold, V., Brumsack, H.-J., 2001. Inorganic geochemistry of Albian sediments from the Lower Saxony Basin NW Germany: palaeoenvironmental constraints and orbital cycles. Palaeogeogr. Palaeoclimatol. Palaeoecol. 174 (1), 121-143.

Retallack, G.J., 2001. A 300-million-year record of atmospheric carbon dioxide from fossil plant cuticles. Nature 411 (6835), 287-290.

Richoz, S., Krystyn, L., Horacek, M., Spötl, C., 2007. Carbon isotope record of the InduanOlenekian candidate GSSP Mud and comparison with other sections. Albertiana 35, 35-40.

Riquier, L., Tribovillard, N., Averbuch, O., Devleeschouwer, X., Riboulleau, A., 2006. The Late Frasnian Kellwasser horizons of the Harz Mountains (Germany): two oxygendeficient periods resulting from different mechanisms. Chem. Geol. 233 (1), 137-155.

Romano, C., Goudemand, N., Vennemann, T.W., Ware, D., Schneebeli-Hermann, E. Hochuli, P.A., Brühwiler, T., Brinkmann, W., Bucher, H., 2013. Climatic and biotic upheavals following the end-Permian mass extinction. Nat. Geosci. 6 (1), 57-60.

Rothman, D.H., Hayes, J.M., Summons, R.E., 2003. Dynamics of the Neoproterozoic carbon cycle. Proc. Natl. Acad. Sci. 100 (14), 8124-8129.

Sansjofre, P., Ader, M., Trindade, R.I.F., Elie, M., Lyons, J., Cartigny, P., Nogueira, A.C.R., 2011. A carbon isotope challenge to the snowball Earth. Nature 478 (7367), 93-96.

Sauvage, L., Riquier, L., Thomazo, C., Baudin, F., Martinez, M., 2013. The late Hauterivian Faraoni "Oceanic Anoxic Event" at Río Argos (southern Spain): an assessment on the level of oxygen depletion. Chem. Geol. 340, 77-90.

Schrag, D.P., Higgins, J.A., Macdonald, F.A., Johnston, D.T., 2013. Authigenic carbonate and the history of the global carbon cycle. Science 339 (6119), 540-543.

Sobolev, S.V., Sobolev, A.V., Kuzmin, D.V., Krivolutskaya, N.A., Petrunin, A.G., Arndt, N.T., Radko, V.A., Vasiliev, Y.R., 2011. Linking mantle plumes, large igneous provinces and environmental catastrophes. Nature 477 (7364), 312-316.

Song, H., Tong, J., Chen, Z., 2009. Two episodes of foraminiferal extinction near the Permian-Triassic boundary at the Meishan section, South China. Aust. J. Earth Sci. 56 (6), 765-773.

Song, H., Wignall, P.B., Tong, J., Bond, D.P.G., Song, H., Lai, X., Zhang, K., Wang, H. Chen, Y., 2012. Geochemical evidence from bio-apatite for multiple oceanic anoxic events during Permian-Triassic transition and the link with end-Permian extinction and recovery. Earth Planet. Sci. Lett. 353, 12-21.

Strasser, A., 1986. Ooids in Purbeck limestones (lowermost Cretaceous) of the Swiss and French Jura. Sedimentology 33 (5), 711-727.

Sun, Y., Joachimski, M.M., Wignall, P.B., Yan, C., Chen, Y., Jiang, H., Wang, L., Lai, X., 2012. Lethally hot temperatures during the Early Triassic greenhouse. Science 338 (6105), 366-370.

Sun, Y., Wignall, P.B., Joachimski, M.M., Bond, D.P.G., Grasby, S.E., Sun, S., Yan, C.B., Wang, L.N., Chen, Y.L., Lai, X.L., 2015. High amplitude redox changes in the late Early Triassic of South China and the Smithian-Spathian extinction. Palaeogeogr. Palaeoclimatol. Palaeoecol. 427, 62-78.

Swanson-Hysell, N., Maloof, A., Halverson, G., Hurtgen, M., 2008. Covariation in the Carbon Isotopes of Carbonate and Organic Carbon Across the Neoproterozoic Bitter Springs Stage. AGU Fall Meeting Abstractspp. 1414.

Thomazo, C., Ader, M., Farquhar, J., Philippot, P., 2009. Methanotrophs regulated atmospheric sulfur isotope anomalies during the Mesoarchean (Tumbiana formation, Western Australia). Earth Planet. Sci. Lett. 279 (1), 65-75.

Thomazo, C., Vennin, E., Brayard, A., Bour, I., Mathieu, O., Elmeknassi, S., Olivier, N., Escarguel, G., Bylund, K.G., Jenks, J., 2016. A diagenetic control on the Early Triassic Smithian-Spathian carbon isotopic excursions recorded in the marine settings of the Thaynes Group (Utah, USA). Geobiology 14 (3), 220-236.

Tian, L., Tong, J., Algeo, T.J., Song, H., Song, H., Chu, D., Shi, L., Bottjer, D.J., 2014. Reconstruction of Early Triassic ocean redox conditions based on framboidal pyrite from the Nanpanjiang Basin, South China. Palaeogeogr. Palaeoclimatol. Palaeoecol. $412,68-79$.

Tong, J., Zakharov, Y.D., Orchard, M.J., Hongfu, Y., Hansen, H.J., 2004. Proposal of Chaohu Section as the GSSP candidate of the Induan-Olenekian Boundary. Albertiana 29, 13-28.

Tribovillard, N., Algeo, T.J., Lyons, T., Riboulleau, A., 2006. Trace metals as paleoredox and paleoproductivity proxies: an update. Chem. Geol. 232 (1), 12-32.

Tribovillard, N., Bout-Roumazeilles, V., Algeo, T., Lyons, T.W., Sionneau, T., MonteroSerrano, J.C., Riboulleau, A., Baudin, F., 2008. Paleodepositional conditions in the Orca Basin as inferred from organic matter and trace metal contents. Mar. Geol. 254 (1), 62-72.

Vennin, E., Olivier, N., Brayard, A., Bour, I., Thomazo, C., Escarguel, G., Fara, E., Bylund, K.G., Jenks, J.F., Stephen, D.A., Hofman, R., 2015. Microbial deposits in the aftermath of the end-Permian mass extinction; a diverging case from the Mineral Mountains (Utah, USA). Sedimentology 62 (3), 753-792.

Wardlaw, B.R., Collison, J.W., 1986. Paleontology and depositon of the Phosphoria formation. Contrib. Geol. 24 (2), 36.

Westermann, S., Caron, M., Fiet, N., Fleitmann, D., Matera, V., Adatte, T., Föllmi, K.B., 2010. Evidence for oxic conditions during oceanic anoxic event 2 in the northern Tethyan pelagic realm. Cretac. Res. 31 (5), 500-514.

Wignall, P.B., Hallam, A., 1992. Anoxia as a cause of the Permian/Triassic mass extinction: facies evidence from northern Italy and the western United States. Palaeogeogr. Palaeoclimatol. Palaeoecol. 93 (1), 21-46.

Wright, V.P., Burgess, P.M., 2005. The carbonate factory continuum, facies mosaics and microfacies: an appraisal of some of the key concepts underpinning carbonate sedimentology. Facies 51 (1-4), 17-23.

Zeebe, R.E., 2012. History of seawater carbonate chemistry, atmospheric CO2, and ocean acidification. Annu. Rev. Earth Planet. Sci. 40, 141-165. 